\title{
Félix: a Late Pleistocene White Whale (Delphinapterus Leucas) Skeleton From Champlain Sea Deposits at Saint-Félix-de-Valois, Québec
}

\section{Félix : un squelette de baleine blanche (Delphinapterus leucas) du Pléistocène supérieur provenant des dépôts de la Mer de Champlain à Saint-Félix-de-Valois}

\author{
C. Richard Harington, Serge Lebel, Maxime Paiement et Anne de Vernal
}

Volume 60, numéro 2, 2006

URI : https://id.erudit.org/iderudit/016828ar

DOI : https://doi.org/10.7202/016828ar

\section{Aller au sommaire du numéro}

\section{Éditeur(s)}

Les Presses de l'Université de Montréal

ISSN

0705-7199 (imprimé)

1492-143X (numérique)

Découvrir la revue

Citer cet article

Harington, C. R., Lebel, S., Paiement, M. \& de Vernal, A. (2006). Félix: a Late Pleistocene White Whale (Delphinapterus Leucas) Skeleton From Champlain Sea Deposits at Saint-Félix-de-Valois, Québec. Géographie physique et Quaternaire, 60(2), 183-198. https://doi.org/10.7202/016828ar

\section{Résumé de l'article}

Un squelette presque complet et articulé d'une vieille baleine blanche (Delphinapterus leucas) provenant des dépôts de la mer de Champlain à Saint-Félix-de-Valois représente le spécimen le mieux conservé du genre en Amérique du Nord. Il s'agit de l'un des 21 spécimens de baleine blanche découvert à ce jour dans les dépôts de la Mer de Champlain. Du collagène extrait d'une vertèbre a donné une date radiocarbone par spectrométrie de masse par accélérateur de $10700 \pm 90 \mathrm{BP}$, laquelle, avec les données stratigraphiques et paléoenvironnementales, est en accord avec nos connaissances actuelles sur la dispersion ancienne de l'espèce, son habitat et son mode de vie. Cette étude livre une esquisse quantitative régionale de la température des eaux de surface, de la salinité et du couvert de glace. Les dinokystes indiquent un changement des conditions de froides à fraîches des eaux de surface durant la période correspondant au retrait glaciaire et au début de l'Holocène. 


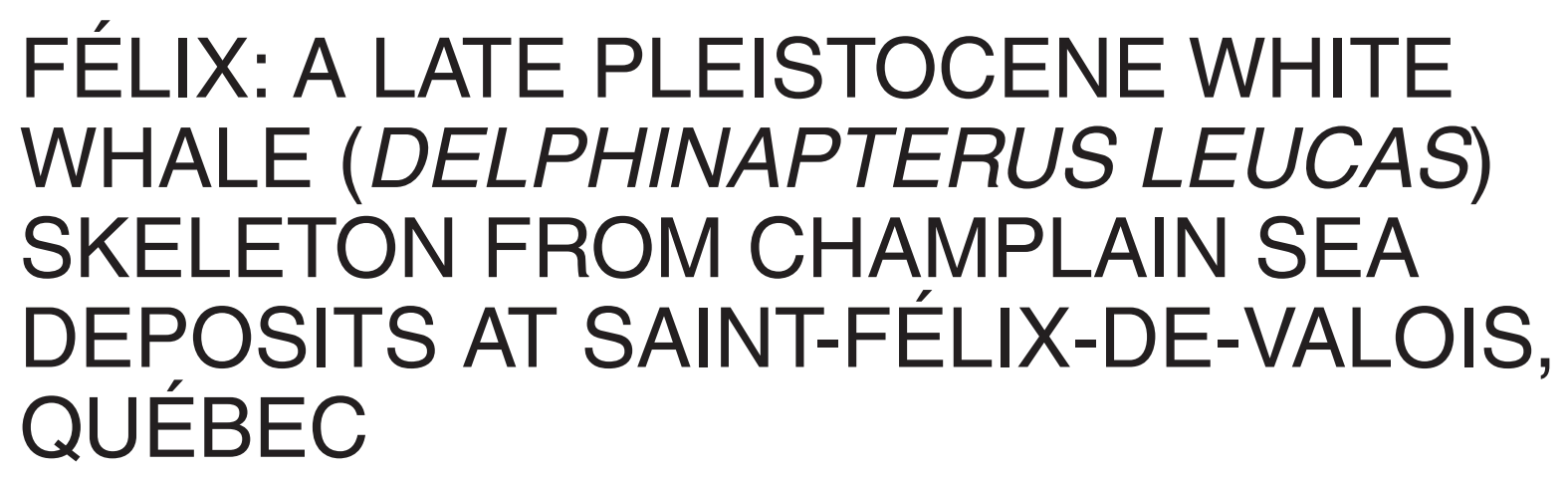

C. Richard HARINGTON*, Serge LEBEL, Maxime PAIEMENT** and Anne de VERNAL; first author: Research Division (Paleobiology), Canadian Museum of Nature, P.O. Box 3443, Station D, Ottawa, Ontario K1P 6P4, Canada; second author: Département des Sciences de la Terre et de l'Atmosphère, Université du Québec à Montréal, C.P. 8888, Succ. Centre-ville, Montréal, Québec H3C 3P8, Canada; third and fourth authors: GEOTOP, Université du Québec à Montréal, C.P. 8888, Succ. Centre-ville, Montréal, Québec H3C 3P8, Canada.

ABSTRACT A nearly complete, articulated skeleton of an old white whale (Delphinapterus leucas) from Champlain Sea deposits at SaintFélix-de-Valois is the best preserved specimen of its kind recorded from North America. It is one of 21 white whale specimens known from Champlain Sea deposits. Collagen from a vertebra yielded an accelerator mass spectrometry radiocarbon date of $10700 \pm 90 \mathrm{BP}$, which, with stratigraphic and paleoenvironmental data, is in accord with our knowledge of the past distribution of this species, its known habitat and habits. This study quantitatively traces regional sea-surface temperature, salinity and ice-cover. Dinocysts indicate a change from cold to cool conditions in surface water during that period corresponding to the withdrawal of ice and the beginning of the Holocene.
RESUME Félix: un squelette de baleine blanche (Delphinapterus leucas) du Pléistocène supérieur provenant des dépôts de la Mer de Champlain à Saint-Félix-de-Valois. Un squelette presque complet et articulé d'une vieille baleine blanche (Delphinapterus leucas) provenant des dépôts de la mer de Champlain à Saint-Félix-de-Valois représente le spécimen le mieux conservé du genre en Amérique du Nord. II s'agit de l'un des 21 spécimens de baleine blanche découvert à ce jour dans les dépôts de la Mer de Champlain. Du collagène extrait d'une vertèbre a donné une date radiocarbone par spectrométrie de masse par accélérateur de $10700 \pm 90 \mathrm{BP}$, laquelle, avec les données stratigraphiques et paléoenvironnementales, est en accord avec nos connaissances actuelles sur la dispersion ancienne de l'espèce, son habitat et son mode de vie. Cette étude livre une esquisse quantitative régionale de la température des eaux de surface, de la salinité et du couvert de glace. Les dinokystes indiquent un changement des conditions de froides à fraîches des eaux de surface durant la période correspondant au retrait glaciaire et au début de l'Holocène.

Manuscrit reçu le 11 novembre 2005; manuscrit révisé accepté le 11 août 2006 (publié le 4e trimestre 2007)

*E-mail address: dharington@mus-nature.ca

** This paper is dedicated to Maxime Paiement who died on August 18, 2006. 


\section{INTRODUCTION}

First, it is useful to provide some facts on the physical characteristics, taxonomic relationship, distribution and social and feeding habits of living white whales (Brodie, 1989; Folkens et al., 2002; Kovacs, 2005). Males reach lengths of $5 \mathrm{~m}$ and weights of $900 \mathrm{~kg}$, whereas females reach a maximum length of $4 \mathrm{~m}$ and $600 \mathrm{~kg}$. Adults are white. They lack a dorsal fin but have a prominent dorsal ridge used to break through thin sea ice. They have small eyes, a bulbous forehead ("melon"), a flexible neck (unlike most whales that have fused neck vertebrae), and relatively small flippers and tail fluke. They live to an age of about 40 years (Kovacs, 2005).

Their closest relative is the narwhal (Monodon monoceras), which also has a circumpolar distribution in Arctic and Subarctic waters (Berta et al., 2006: p. 80). The present white whale total population may be about 200000 . A small southern population, possibly a remnant of the Champlain Sea stock, survives in the St. Lawrence River estuary (Sergeant and Hoek, 1988). They are gregarious and seem to prefer coastal waters and bays, feeding mainly on fishes, squids and prawns (Hall, 1981). In summer they often gather at river estuaries, where they may feed on seasonally abundant coastal fishes (Kovacs, 2005).

Marine mammals have played a prominent part in our knowledge of the Quaternary history of Québec since Per Kalm (1749), a Swedish botanist, was informed of a whale skeleton found inland from the St. Lawrence River near Québec City (Harington, 2003a, 2003b). Five species of whales, particularly adapted to inshore conditions, have been reported from Champlain Sea (an inundation of the St. Lawrence Lowlands by Atlantic Ocean waters between about 13100 and 10600 years ago, $11100-9400{ }^{14} \mathrm{C}$ BP; Ochietti and Richard, 2003) deposits. Most specimens (about 80\%) represent white whales (Fig. 1, Table I; Harington 1988). The most complete of these is "Félix", a skeleton excavated in place near the village of Saint-Félix-de-Valois, Québec in 2001 (Société de Paléontologie du Québec, 2002). Félix is not only important because of its completeness, but also because its stratigraphic context, individual age, radiocarbon age and microfossils revealing its paleoenvironment are known.

The purpose of this paper is to describe and figure the skeleton, discuss the discovery and excavation of the specimen, its locality, stratigraphic context, radiocarbon age, burial position, taphonomy, paleogeography and paleoenvironment - based mainly on studies of associated fossil pollen and spores, foraminifera and dinocysts.

\section{DISCOVERY}

On July 20th, 2001, Monique Hénault, a farmer, accidentally discovered a few large bones on her property at SaintFélix-de-Valois in the Lanaudière region of Québec. She was surprised to find them near a drainage ditch made by a backhoe. In an effort to find out what kind of animal they represented, she showed one to a local veterinarian, who, not recognizing its significance, discarded it. This accounts for the one missing vertebra - an eighth thoracic!
At the beginning of August, the Société de Paléontologie du Québec (SPQ) was called to investigate the site, and identified a marine mammal. The SPQ asked one of us (Serge Lebel) to supervise excavation of the specimen, most of which apparently still lay below the surface. Aided by a team of SPQ volunteers, the work was completed in slightly less than two weeks.

\section{EXCAVATION}

By cutting a large trench $3 \mathrm{~m}$ deep and NW-SE in orientation in the farm field, the backhoe operator revealed an undisturbed sequence of marine sediments of Champlain Sea age. A large cluster of bones lying horizontally along a bedding plane was exposed $1.2 \mathrm{~m}$ below the present land surface. Thus the lateral extent of the specimen and its width could be ascertained. The method of excavation was adapted to the nature of the site, probing horizontally and vertically so that as little energy was expended as possible. To save time, the backhoe was used to gradually and cautiously strip away the overburden including the topsoil (about $90 \mathrm{~cm}$ thick). Thus, the critical area (about $20 \mathrm{~m}^{2}$ ) was stripped without deforming or compressing the underlying fossil-bearing layer. Then the in situ skeleton was carefully exposed using small hand tools. Matrix was removed around the bones so that they were exposed horizontally in their natural position.

The position of each bone was recorded on large, detailed overhead photographs prior to its numerical labelling, which incorporated data on articulation with or relationship to adjacent bones. Thus, each skeletal element could be associated with its specific natural position.

However, during the preliminary excavation of the trench the backhoe operator accidentally scooped up part of the vertebral column, including some lumbar and caudal vertebrae and part of a scapula. SPQ volunteers carefully collected these disturbed bones by sifting through piles of sediment deposited along the trench. Ultimately, 17 missing vertebrae were relocated, and their broken neural and transverse spines repaired where possible.

As the bones were exhumed, they showed signs of physical deterioration. Some were exfoliating and cracking. To stabilize them a consolidant (Acryloid B72) was applied in the field. Specimens were then removed to the laboratory for further cleaning, drying and repair prior to accessioning.

\section{LOCALITY AND STRATIGRAPHY}

The fossil locality $\left(73^{\circ} 25^{\prime} 26^{\prime \prime} \mathrm{W}, 46^{\circ} 12^{\prime} 20^{\prime \prime} \mathrm{N}\right.$, about $135 \mathrm{~m}$ asl; Fig. 2) is $4.5 \mathrm{~km} \mathrm{NW}$ of the village of Saint-Félix-de-Valois. The township is about $90 \mathrm{~km}$ NE of Montréal and some $23 \mathrm{~km}$ NW of the St. Lawrence River. In many ways it is a border region. Topographically it lies where the St. Lawrence Lowlands and Laurentian Highlands meet. North of the locality the contact between these two physiographic areas consists of relatively high escarpments between 230 and 319 m asl. 


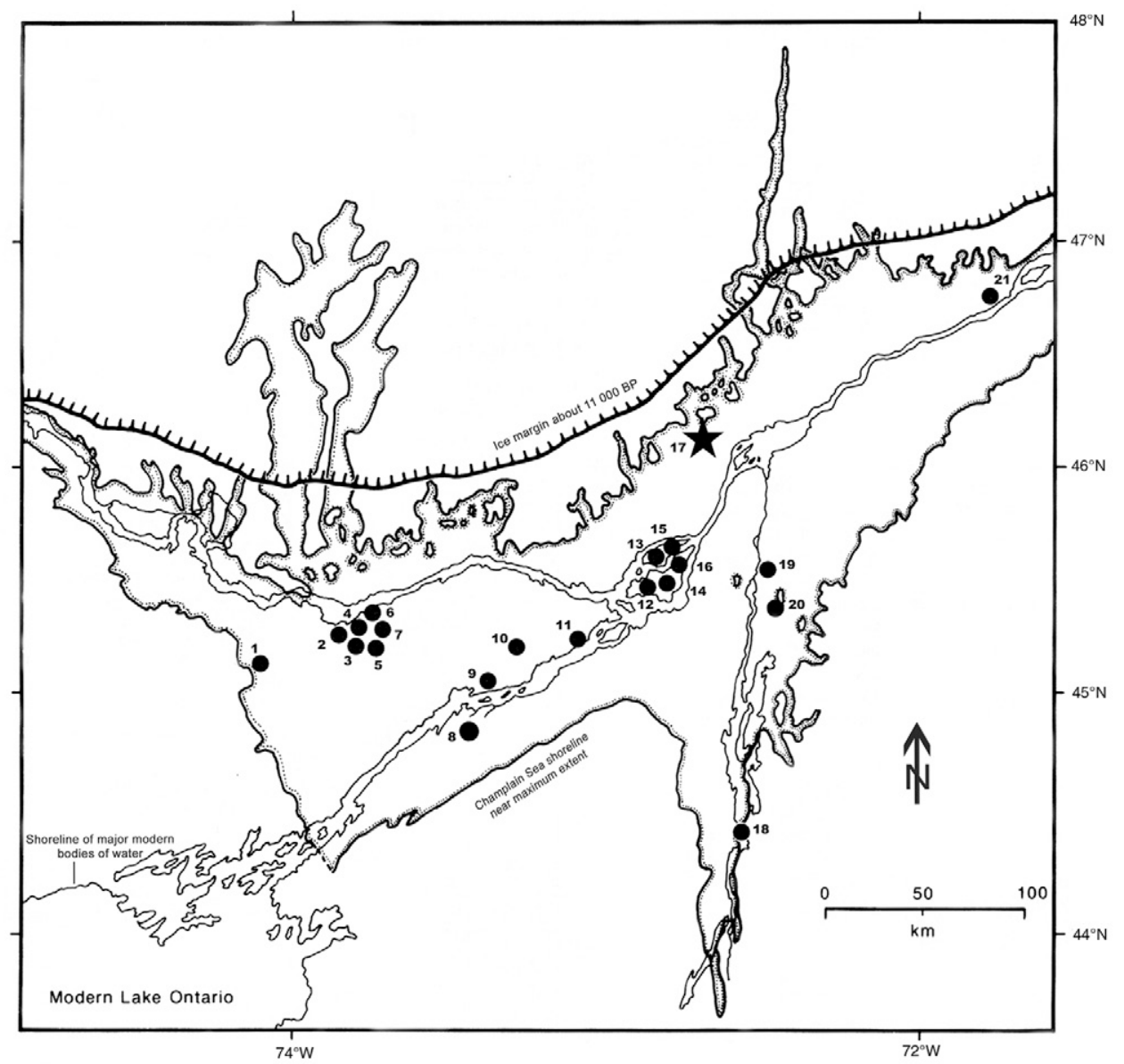

FIGURE 1. Known localities and radiocarbon ages of Champlain Sea white whale fossils (Harington, 1988; Steadman et al., 1994; this paper). The black star marks the Saint-Félix-de-Valois fossil locality. Key: 1. Pakenham, Ontario [CMN 21336; $10400 \pm 80$ BP (GSC2418)]; 2. Ottawa, Ontario (CMN 8883); 3. Rideau Junction, Ontario (CMN 17628); 4. Ottawa, Ontario (CMN 8884); 5. Jock River, Ontario (CMN 421); 6. Ottawa, Ontario (CMN 2219); 7. Ottawa, Ontario [collected in 1956, in N.R. Gadd collection; $10420 \pm 150$ BP (GSC-454)]; 8. Norfolk, New York [NYSM 5095; $10450 \pm 140$ BP (Beta-25252)]; 9. Cornwall, Ontario (CMN 6842); 10. Williamstown, Ontario (RM 12734); 11. Coteau Station, Québec (present location unknown); 12. Montréal, Québec (RM, catalogue number unknown); 13. Montréal, Québec (CMN 6833); 14. Montréal, Québec (RM 12732); 15. Montréal, Québec (catalogue number unknown); 16. Montréal, Québec (RM 13831); 17. Saint-Félix-de-Valois, Québec [SPQ 100; $10700 \pm 90$ BP (TO-9996)]; 18. Montpelier, Vermont (catalogue number unknown); 19. Mont-Saint-Hilaire, Québec [(CMN uncatalogued; $9470 \pm 170$ BP (Beta-27511)]; 20. Saint-Césaire, Québec (CMN 52544); 21. SaintNicolas, Québec (CMN 12432).

The exposed stratigraphic sequence consists of three units (Fig. 3): unit 1 is more than $2 \mathrm{~m}$ thick and consists of a massive, unstratified bed of blue clay (marine clay and silt) deposited in deep water (inundation phase) of the Champlain Sea. It contains few fossils.

Unit 2, overlying unit 1, is about 30 m thick and consists of horizontal bands of alternating clay or silty clay (each about 5 to $6 \mathrm{~cm}$ thick), and highly-oxidized, fine sandy lenses a few
Localisation et âges ${ }^{14} \mathrm{C}$ des fossiles de baleines blanches de la Mer de Champlain (Harington, 1988; Steadman et al., 1994; cet article). L'étoile indique la localité de Saint-Félix-de-Valois. Légende: 1. Pakenham, Ontario [CMN 21336; $10400 \pm 80$ BP (GSC-2418)]; 2. Ottawa, Ontario (CMN 8883); 3. Rideau Junction, Ontario (CMN 17628); 4. Ottawa, Ontario (CMN 8884); 5. Jock River, Ontario (CMN 421); 6. Ottawa, Ontario (CMN 2219); 7. Ottawa, Ontario [recueilli en 1956, dans la collection de N.R. Gadd; $10420 \pm 150$ BP (GSC-454)]; 8. Norfolk, New York [NYSM 5095; $10450 \pm 140$ BP (Beta-25252)]; 9. Cornwall, Ontario (CMN 6842); 10. Williamstown, Ontario (RM 12734); 11. Station Coteau, Québec (localisation inconnue); 12. Montréal, Québec (RM, numéro inconnu); 13. Montréal, Québec (CMN 6833); 14. Montréal, Québec (RM 12732); 15. Montréal, Québec (numéro de catalogue inconnu); 16. Montréal, Québec (RM 13831); 17. Saint-Félix-de-Valois, Québec [SPQ 100; $10700 \pm 90$ BP (TO-9996)]; 18. Montpelier, Vermont (numéro de catalogue inconnu); 19. Mont-Saint-Hilaire, Québec [(CMN non catalogué; $9470 \pm 170$ BP (Beta-27511)]; 20. Saint-Césaire, Québec (CMN 52544); 21. SaintNicolas, Québec (CMN 12432).

centimetres thick. It comprises fossiliferous littoral (nearshore) sands, sandy alluvial fans and bars, stratified silts deposited in intertidal zones, as well as deltaic sediments marking a regressive phase of the Champlain Sea (Parent and Occhietti, 1988). Most of the white whale skeleton was embedded in wet siltyclay at the base of this unit. The surrounding matrix yielded remains of the following marine invertebrates: Mya arenaria, Hiatella arctica and Mytilus edulis shells, and starfish such as 


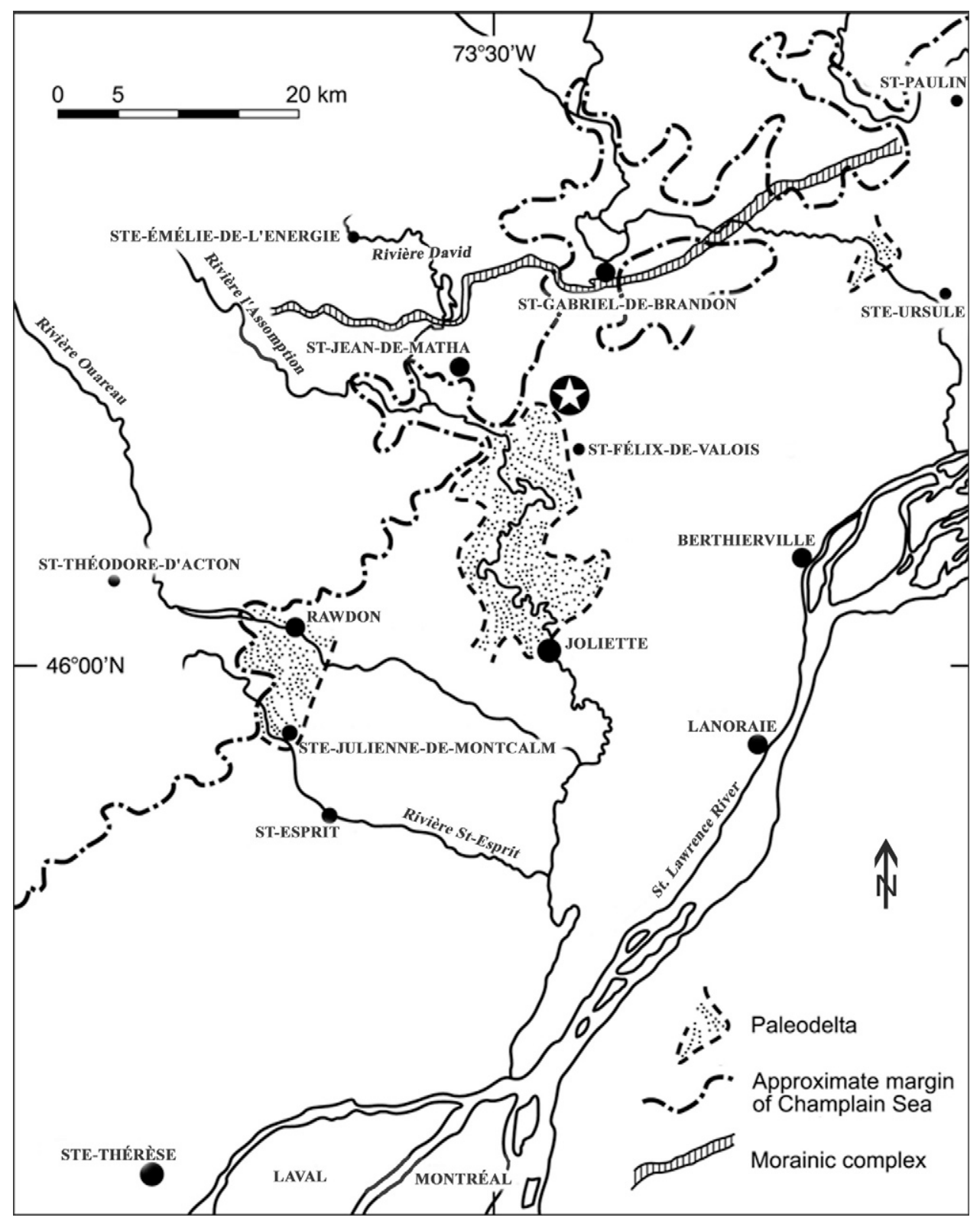

FIGURE 2. Fossil locality (white star) near Saint-Félix-de-Valois, Québec and surrounding region north of Montréal. Félix was found near the northeastern margin of the l'Assomption paleodelta. The approximate margin of the Champlain Sea, the Saint-Narcisse Moraine (Denis and Prichonnet, 1973), as well as three paleodeltas are marked. A walrus skull was found at Sainte-Julienne-deMontcalm near the edge of another Champlain Sea paleodelta about $35 \mathrm{~km}$ SW of the Saint-Félix-deValois locality (Bouchard et al., 1993; Harington et al., 1993; Dyke et al., 1999).

Localisation du fossile (étoile) près de Saint-Félix-de-Valois, Québec et de la région avoisinante au nord de Montréal. Félix a été découvert à proximité de la marge nord-est du paléodelta de l'Assomption. Les marges approximatives de la Mer de Champlain, de la moraine de Saint-Narcisse (Denis et Prichonnet, 1973) et de trois paléodeltas sont indiqués. Un crâne de morse a été découvert à SainteJulienne-de-Montcalm à proximité d'un autre paléodelta de la Mer de Champlain situé à environ $35 \mathrm{~km}$ au sud-ouest de la localité de Saint-Félix-de-Valois (Bouchard et al., 1993; Harington et al., 1993; Dyke et al., 1999).

Ophiura. This assemblage compares well with Cronin's (1977) Mya phase fauna (11000 to $10600 \mathrm{BP}$ ) of the Champlain Sea, and suggests climatic amelioration and the diminishing influence of glacial ice on water temperature. Moreover, the sediments and fossils indicate that a shallow water habitat, within the intertidal zone, prevailed during deposition of the whale.

Unit 3, overlying unit 2, is about $90 \mathrm{~cm}$ thick and consists of a contemporary soil (clay covered with vegetation modified by agricultural processes). The clay is bluish at the base, becoming brownish toward the top.

\section{RADIOCARBON AGE}

Accelerator mass spectrometry (AMS) radiocarbon dating of bone collagen derived from a vertebra yielded an uncali- brated date of $10700 \pm 90 \mathrm{BP}$ (TO-9996). This result is the average of two separate analyses (normal precision) and is corrected for natural and sputtering isotope fractionation to a base of $\delta^{13} \mathrm{C}=-25 \%$, using the measured ${ }^{13} \mathrm{C} /{ }^{12} \mathrm{C}$ ratio. The Libby ${ }^{14} \mathrm{C}$ mean life of 8033 years is used. The error represents $68.3 \%$ confidence limit. This places the death of the whale close to the northern margin of the Champlain Sea when it was near its maximum extent (Fig. 2).

This date is slightly older than others based on Champlain Sea white whale bone collagen analyses: (a) $10450 \pm 40$ BP (Beta-25252) from Norfolk, New York State (Steadman et al., 1994), (b) $10420 \pm 150$ BP (GSC-454) from Foster Sand Pit, Ottawa, Ontario (Harington, 1977, 1978, 1988; Harington and Occhietti, 1988), and (c) $10400 \pm 80$ BP (GSC-2418) from a site 6 km NW of Pakenham, Ontario (Harington, 1977, 1978; Harington and Occhietti, 1988). A date of $9470 \pm 170 \mathrm{BP}$ 


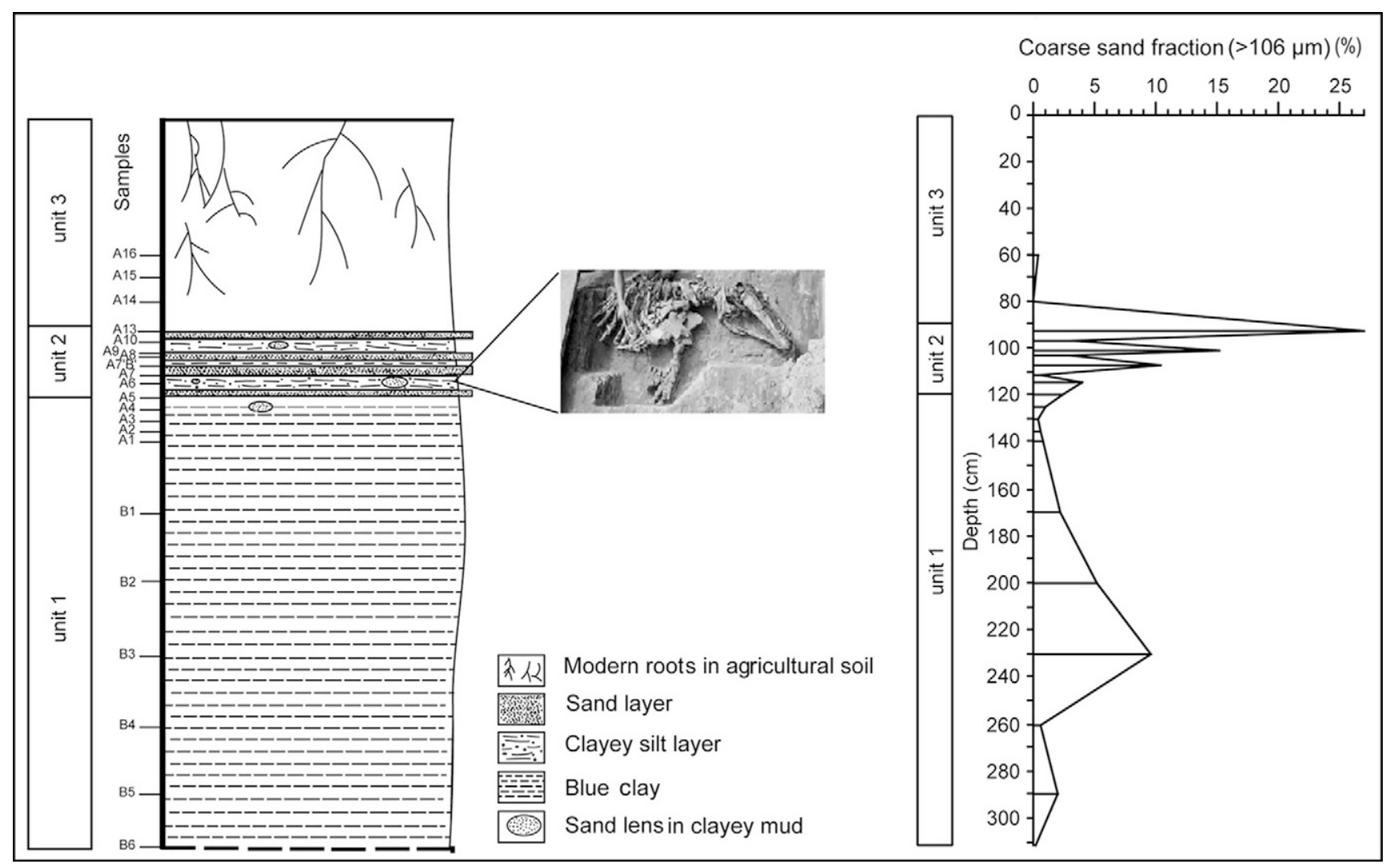

FIGURE 3. Stratigraphic section at the Saint-Félix-de-Valois fossil locality (left) showing three units and the position of Félix (top centre picture) near the base of unit 2. Micropaleontological sampling levels run from $A 1$ to $A 16$ and $B 1$ to $B 6$. The diagram (right) shows percentages of coarse $(>106 \mu \mathrm{m})$ sand in various samples along with depths in $\mathrm{cm}$ from the top down.

(Beta-27511) from a sandpit on the south side of Mont-SaintHilaire, Québec, seems unusually young and should be reassessed (Harington, 1988, 2003a, 2003b, p. 352; and see dates on marine samples in Table III of Occhietti and Richard, 2003).

\section{ABBREVIATIONS}

AW(max.) - Anterior width (maximum) (mm)

Beta - Beta Analytic Inc. radiocarbon laboratory in Miami, Florida

CMN - Canadian Museum of Nature

GSC - Geological Survey of Canada, or its radiocarbon laboratory in Ottawa

LGC - Length of glenoid cavity $(\mathrm{mm})$

$\mathrm{MAL}$ - Maximum anteroposterior length $(\mathrm{mm})$

MAN - Maximum anteroposterior length of "neck" (mm)

MDC - Maximum depth (anteroposterior) of centrum ( $\mathrm{mm}$ )

MDD - Maximum distal depth $(\mathrm{mm})$

$\mathrm{MDL}$ - Maximum distal length $(\mathrm{mm})$

MDL(min.) - Midline length (minimum) (mm)

MDV - Maximum depth (anteroposterior) of vertebra $(\mathrm{mm})$

$\mathrm{MH}$ - Maximum height $(\mathrm{mm})$
Coupe stratigraphique de la localité fossile à Saint-Félix-de-Valois (gauche) montrant les trois unités et la position de Félix (photo du centre) près de la base de l'unité 2. Les niveaux de l'échantillonnage micropaléontologique vont de $A 1$ à $A 16$ et de $B 1$ à $B 6$. Le diagramme (droite) montre les pourcentages de sable grossier $(>106 \mu \mathrm{m})$ dans différents échantillons selon la profondeur en $\mathrm{cm}$ et de haut en bas.

$\mathrm{MHC}$ - Maximum height of centrum on midline $(\mathrm{mm})$

MHS - Maximum height of scapula (anterior margin of glenoid cavity to dorsal margin of scapula) $(\mathrm{mm})$

MHV - Maximum height of vertebra $(\mathrm{mm})$

$\mathrm{ML}$ - Maximum length ( $\mathrm{mm}$ )

MLD - Midline depth ( $\mathrm{mm})$

MLDC - Midline depth (anteroposterior) of centrum ( $\mathrm{mm}$ )

MLN - Minimum length at notches $(\mathrm{mm})$

MLTH - Maximum length across tubercle and head facets (mm)

MMD - Minimum midshaft depth (mm)

$\mathrm{MMH}$ - Maximum midline height $(\mathrm{mm})$

MMW - Minimum midshaft width $(\mathrm{mm})$

MPL - Maximum proximal (anteroposterior) length $(\mathrm{mm})$

MPD - Maximum proximal (mediolateral) depth $(\mathrm{mm})$

MSD - Minimum shaft depth ( $\mathrm{mm})$

MSL - Minimum shaft length $(\mathrm{mm})$

MW - Maximum width ( $\mathrm{mm}$ )

MWC - Maximum width of centrum $(\mathrm{mm})$

MWGC - Maximum width of glenoid cavity $(\mathrm{mm})$

MWTP - Maximum width at transverse processes $(\mathrm{mm})$

MWV - Maximum width of vertebra $(\mathrm{mm})$

$\mathrm{PW}(\max$.$) - Posterior width (maximum) (mm)$ 
RM - Redpath Museum

SPQ - Société de Paléontologie du Québec

$\mathrm{TL}$ - total length $(\mathrm{mm})$

TLI - Total length on inside of curve $(\mathrm{mm})$

\section{DESCRIPTION}

Order: Cetacea Brisson, 1762

Family: Monodontidae Gray, 1821

Genus: Delphinapterus Lacépède, 1804

Delphinapterus leucas Pallas, 1776 (white whale or beluga)

The specimen called "Félix" (SPQ 100, kept in the Société de Paléontologie du Québec collection in Montréal) consists of a nearly complete skeleton of a white whale (or beluga) approximately 60 years old according to Dr. David Sergeant's (pers. comm., 2004) microscopic examination of annuli (growth layers) counted in a longitudinal section through a nearly unworn tooth. A slide and polished section of the tooth, CMN 52268, are available for examination in the CMN Quaternary Zoology Collection. This may be a record for longevity in white whales (Watson, 1981; McAlpine et al., 2001; Kovacs, 2005). However, Dr. Veronique Lesage (pers. comm., 2007) inform me that, since it has been determined that growth layer groups in white whale teeth form annually and not semiannually (Stewart et al., 2006), a lactating female from Escuminac, New Brunswick (McAlpine et al., 1999) 'would in fact be 66 yearsold'. Sergeant comments that Félix "is a very old animal that must have died of natural causes, e.g., old age". Furthermore, he states: "I would deduce it [Félix] is probably a male animal with larger skeletal growth, also expressed in the teeth as wider cemental layers, and thicker terminal dentinal layers". This observation is supported by the degree of suture fusion of the bones and degree of wear on most of the teeth. Indeed, the relatively large size of the specimen suggests that it may represent a male, because adult males are larger on the average (TL about 335-485 cm) than females (about $300-400 \mathrm{~cm}$ ) (Nowak and Paradiso, 1983: p. 897). An approximation of the total length of Félix as preserved in the field is at least $450 \mathrm{~cm}$ - within the upper range of modern males, and well beyond the upper range for modern females. The maximum depth of

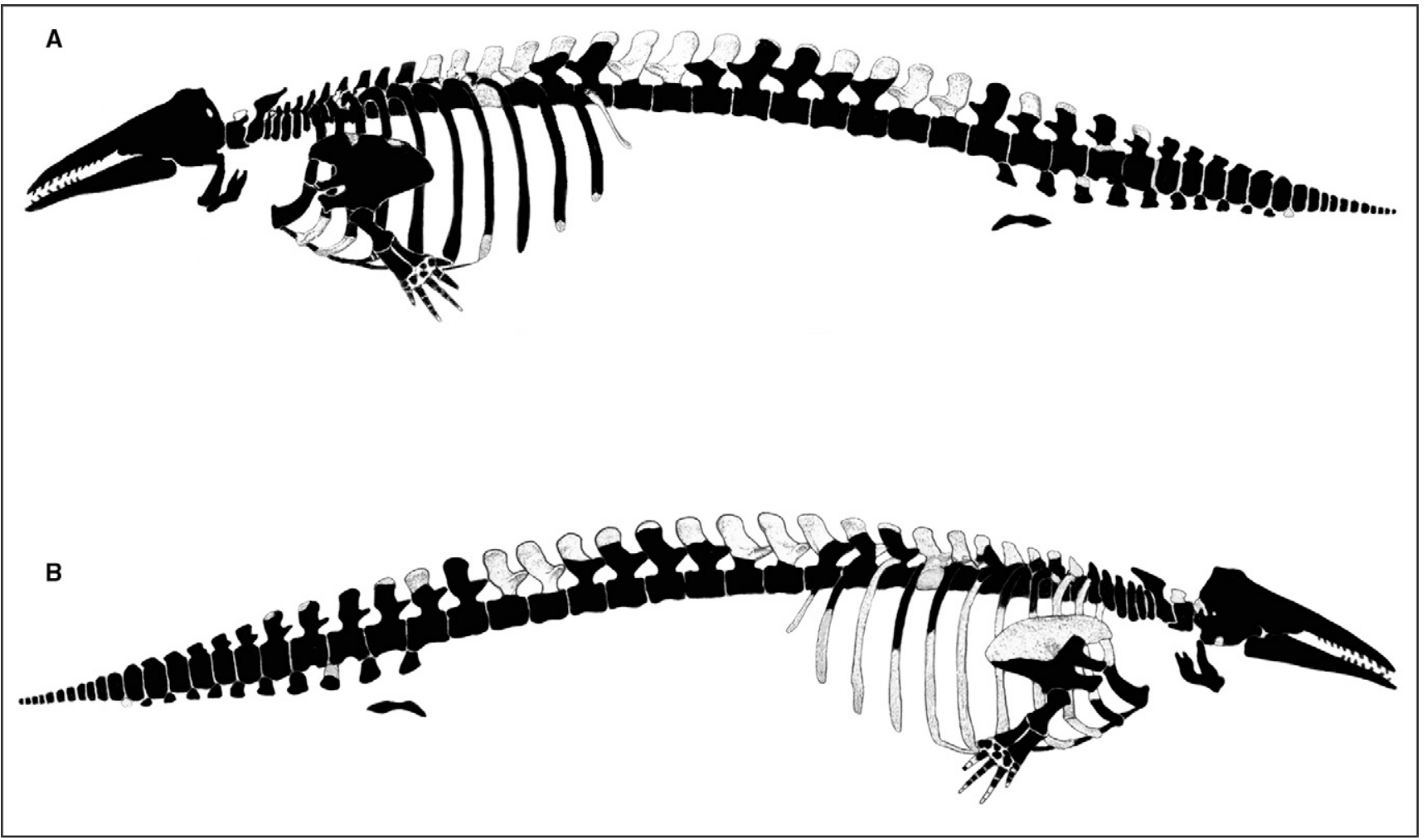

FIGURE 4. (A) Diagrammatic view of left side of the skeleton of Félix. (B) Diagrammatic view of the right side. Blackened areas indicate bones present. The skeletal outline of the white whale is derived from van Beneden and Gervais (1880, Plate XLIV). Félix is estimated to be 95\% complete compared to two specimens from Montréal in the Redpath Museum (Ingrid Birker, pers. comm., 2005) which are about $75-80 \%$ (Dawson, 1895) and 60-65\% (Ardley, 1916), and a specimen from Cornwall, Ontario about $60 \%$ complete (Billings, 1870). Note that uncatalogued fragments of many bones of Félix are preserved but have no apparent fits with the more complete elements shown.
(A) Vue schématique du côté gauche du squelette de Félix. (B) Vue schématique du côté droit du squelette de Félix. Les zones noires indiquent les os préservés. Le schéma du squelette est tiré de van Beneden et Gervais (1880, planche XLIV). Félix a été estimé complet à $95 \%$ en comparaison au spécimen de Montréal conservé au Musée Redpath (Ingrid Birker, comm. pers., 2005) complet à 75-80\% (selon Dawson, 1895) ou 60-65 \% (selon Ardley, 1916); un spécimen de Cornwall, Ontario, serait complet à environ $60 \%$ (Billings, 1870). II faut noter que plusieurs fragments d'os non catalogués de Félix sont conservés, mais n'ont pu être raccordés aux éléments osseux plus complets qui sont montrés ici. 
the skeleton as preserved (the bones were compressed in the sedimentary sequence) was about $25 \mathrm{~cm}$ at the level of the ribcage.

Parts of the skeleton that are preserved, an estimated $95 \%$ of the entire specimen (Fig. 4A-B), follow. Many fragments of transverse processes and neural spines of vertebrae, as well as pieces of ribs and sternal ribs damaged by the backhoe, have not been identified specifically due to lack of "fits". And, of course, the eighth thoracic was present.

\section{CRANIUM (SPQ 100-1, FIGS. 5-6, TABLE I)}

Complete, with six worn upper teeth and three empty alveoli on each side of the upper jaw, except for the anterior half of the right zygomatic, as well as breaks in the right and left basioccipital region measuring approximately $80 \times 46 \mathrm{~mm}$ and $34 \times 18 \mathrm{~mm}$ respectively. Both auditory bullae (SPQ 100-2, 3) were preserved separately from the cranium.

\section{MANDIBLE (SPQ 100-4, FIG. 7, TABLE I)}

Complete. The left dentary has worn teeth in the five anterior sockets (the three posterior alveoli lack teeth), whereas the right dentary has seven worn teeth filling all of the alveoli. The posterior third of the right dentary was broken away, but has been repaired. Fig. 8 shows the anterior portion of the skeleton as excavated including the skull, hyoid bones, neck vertebrae, part of the left and right manus, sternum and sternal ribs.

\section{HYOID APPARATUS}

Left and right stylohyals (SPQ 100-5, 6; ML168.0, MW32.5), and the suspended ceratobranchials (SPQ 100-7; MDL(min.)82.0, AW(max.)67.4, PW(max.)279.3) are present.

\section{VERTEBERAE}

\section{Cervical}

All seven are preserved. The atlas (C1, SPQ 100-8) lacks only the upper left part of the bone covering the neural canal (MW212.5, MLD70.0). The axis (C2, SPQ 100-9) is complete (MW192.2, MLD39.4, MMH171.2). The third cervical (C3, SPQ 100-10) lacks bone over the centre of the neural arch and the transverse processes are slightly damaged (MW136.0+, MDC25.8, MWC86.3, MHC59.3). The fourth cervical (C4, SPQ 100-11) is complete except for damage to the end of the right transverse process (MWC75.2, MHC60.0, MHV118.3, MDC24.7). The fifth cervical (C5, SPQ 100-12) lacks only the right transverse process (MAWC67.7, MADC58.6, MDC25.7, MHV118.5). The sixth cervical (C6, SPQ 100-13) is complete, except for damage to bone enclosing the right side of the neural canal (MWC66.3, MHC59.4, MDC28.4, MHV124.0). The seventh cervical (C7, SPQ 10014 is complete, except that the tips of the articular processes are worn (MWC70.4, MHC58.8, MDC32.5, MHV134.6).
TABLE I

Skull measurements $(\mathrm{mm})$ of the Saint-Félix-de-Valois white whale (Delphinapterus leucas, SPQ 100-1, 4)

\begin{tabular}{llr}
\hline Cranium & \\
& Condylobasal length & 640.0 \\
& Basal length & 593.0 \\
Interorbital width (min.) & 310.0 \\
Greatest width (zygomatic width) & 340.0 \\
Occipital condylar width (max.) & 163.3 \\
Width of blow hole (max.) & 75.3 \\
Width of braincase below nuchal crest & 226.4 \\
Occipital height (max., lower lip of foramen & \\
magnum to peak of skull anterior to nuchal & \\
crest) & 212.4 \\
Mandible & \\
& Length along midline (max.) & 465.0 \\
& Length of dentary (max.) & 480.0 \\
& Width (max.) & 271.0 \\
Coronoid height (max.) & 120.2 \\
& Length of symphysis (max.) & 86.0 \\
\hline
\end{tabular}

Thoracic

All 11 are preserved, except for the eighth, which was accidentally discarded (see Discovery section). Most of these vertebrae are damaged. The first thoracic (T1, SPQ 100-15) is complete except for damage to the neural spine (MWTP188.8, MWC67.8, MHC54.8, MDC47.8. The second thoracic (T2, SPQ 100-16) lacks the right side of the neural canal with the transverse process and the upper part of the left side except for the transverse process (MWC66.7, MHC 53.7, MDC54.5). The third thoracic (T3, SPQ 100-17) lacks the right side of the neural spine (MWC62.3, MHC53.8, MDC59.6). The fourth thoracic (T4, SPQ 100-18) lacks most of the right side of the neural canal with the transverse process, as well as most of the neural spine (MWC62.3, MHC53.1, MDC61.7). The fifth thoracic (T5, SPQ 100-19) lacks the right side of the neural canal with the transverse process and the upper part of its left side (above the last transverse process) (MWC63.7, MHC55.8, MDC67.6). The sixth thoracic (T6, SPQ 100-20) lacks most of the neural spine, bone enclosing the right upper region of the neural canal, and bone on the left side of the anterior epiphyseal plate is eroded (MWV148.1, MWC71.4, MHC57.7, MDC72.9). The seventh thoracic (T7, SPQ 100-21) lacks the left side of the neural canal with the transverse process and the upper part of the right side above the transverse process, and there are large flakes missing from the lower left part of the centrum (anterior and posterior portions) (MWC74.1, MHC60.6, MDC77.9). The eighth thoracic (T8) is missing. The ninth thoracic (T9, SPQ 100-22) is complete except for the articular portion of the right transverse process and the upper two-thirds of the neural spine (MWC68.9, MHC62.8, MDC83.7). The tenth thoracic (T10, SPQ 100-23) lacks the anterior lower right part of the centrum, the articular portion of the right transverse process, the right anterior process and most of the neural spine (MWC72.1, MHC64.2, MDC88.3). The eleventh thoracic (T11, SPQ 100-24) lacks the anterior lower left portion of the centrum, the upper part of the neural 


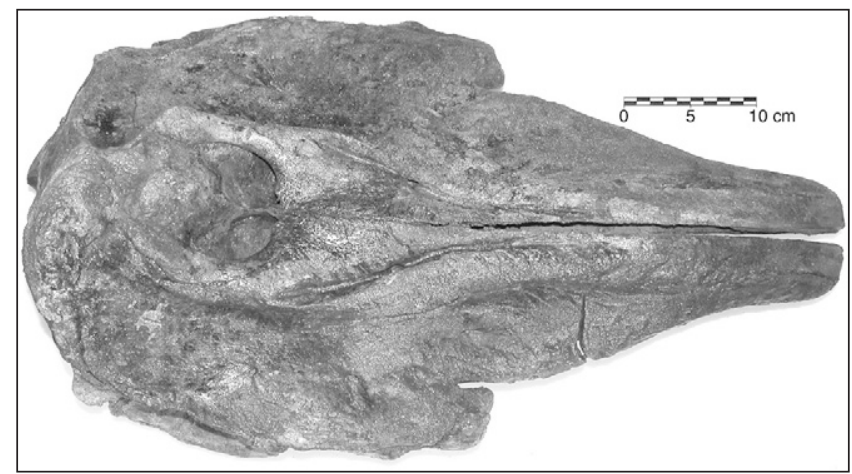

FIGURE 5. Dorsal view of the cranium of Félix. Note blowhole in centre.

Vue dorsale du crâne de Félix. Notez l'évent au centre.

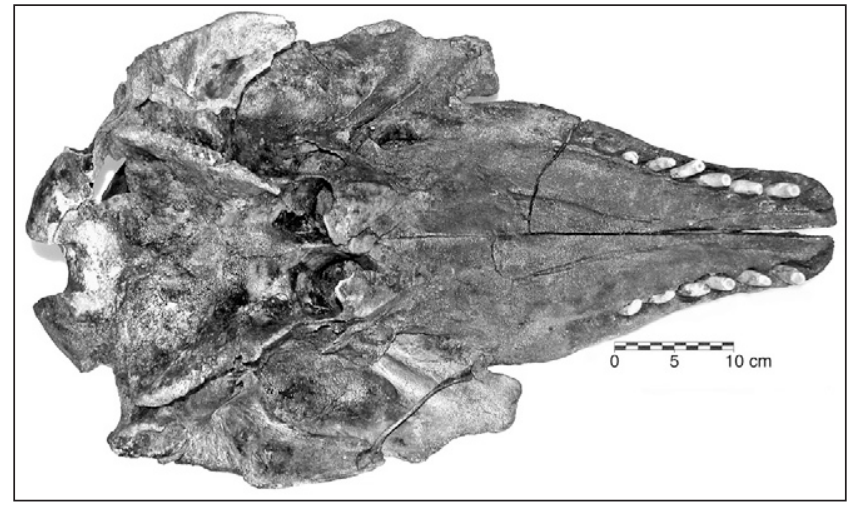

FIGURE 6. Ventral (palatal) view of the cranium of Félix. Note teeth and empty sockets (alveoli).

Vue ventrale (palais) du crâne de Félix. Notez les dents et les alvéoles.

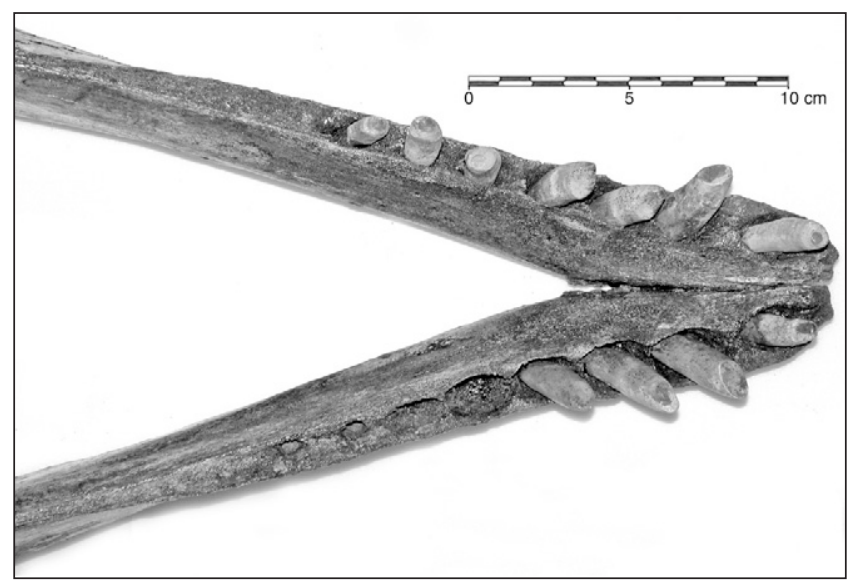

FIGURE 7. Dorsal (occlusal) view of the anterior part of the mandible of Félix. The posterior third of the right dentary was broken away, but has been refitted.

Vue occlusale de la partie antérieure de la mâchoire inférieure de Félix. La partie postérieure droite du corps dentaire a été brisée, mais a pu être remontée. canal and most of the right transverse process with articular surface; the left transverse process has the rib articulation facet but lacks the anterior process (MWC80.6, MHC67.0, MDC94.3).

\section{Lumbar}

All nine lumbar vertebrae are represented. The first lumbar (L1, SPQ 100-25) is complete except for most of the left transverse process and the tip of the right transverse process (MWC81.9, MHC69.4, MDC101.0). The second lumbar (L2, SPQ 100-26) lacks most of the bone surrounding the neural canal, the left transverse process and the tip of the right transverse process (MWC77.1, MHC69.4, MDC101.0). The third lumbar (L3, SPQ 100-27) lacks most of the neural spine, the left transverse process and the tip of the right transverse process (MWC77.5, MHC75.2, MDC106.8). The fourth lumbar (L4, SPQ 100-28) is complete except for most of the left transverse process and the tip of the right transverse process (MHV258.8, MWC78.9, MDC109.3). The fifth lumbar (L5, SPQ 100-29) has a pronounced anterior keel, and lacks the tip of the neural spine, most of the left transverse process and the tip of the right transverse process (MWC80.0, MHC(posterior plate)80.9, MCD110.8). The sixth lumbar (L6, SPQ 10030 ) has a slight anterior keel and lacks the dorsal half of the neural spine; anterior processes are complete (MWC85.3, MHC83.8, MDC114.2). The seventh lumbar (L7, SPQ 100-31) is in similar condition to the second lumbar except that it lacks a piece of bone near the right posterodorsal margin of the centrum (MWC91.4, MHC94.7, MDC117.2). The eighth lumbar (L8, SPQ 100-32) lacks the dorsal half of the neural spine, the distal half of the left transverse process, the tip of the right transverse process and half of the right anterior process

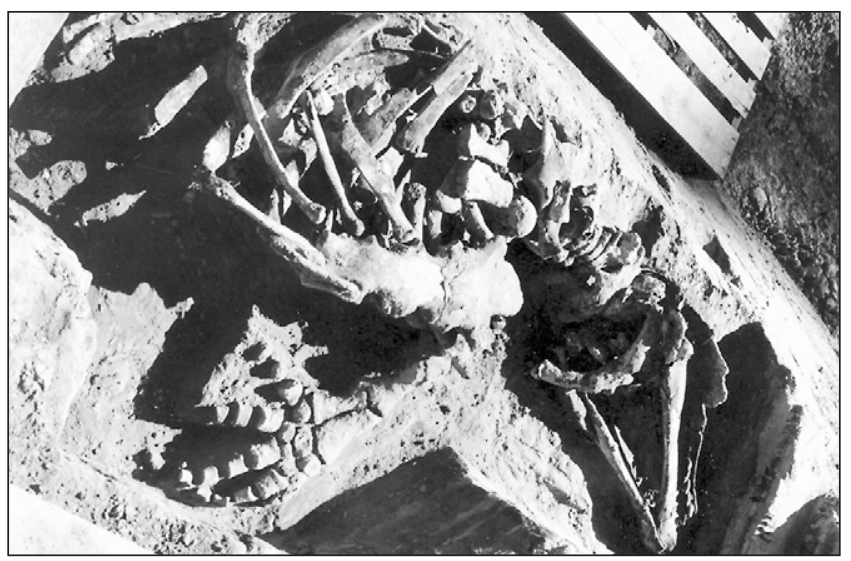

FIGURE 8. Anterior portion of Félix during excavation showing right underside with (from right to left) skull, hyoid apparatus, cervical vertebrae, sternum with sternal ribs, parts of left and right manus and right ribs.

Vue de Félix au cours des fouilles, montrant dans sa partie antérieure le côté droit du squelette (de droite à gauche) l'os hyoïde, les vertèbres cervicales, le sternum avec des côtes sternales, des parties osseuses gauches et droites des nageoires. 
(MWC89.6, MHC89.4, MDC118.9). The ninth lumbar (L9, SPQ 100-33) is in similar condition to the first and second lumbar vertebrae (MWC91.2, MHC100.1, MDC118.2). It is worth noting the gradual increase in MCD of this lumbar series from the first (101.0) to a maximum at the eighth (118.9).

\section{Caudal}

Twenty-two caudal vertebrae are preserved, the last 16 being nearly complete. The first caudal (CA1, SPQ 100-34) lacks most of the transverse processes (MHV23.0, MWC94.3, MHC100.2, MDC109.8). The second caudal (CA2, SPQ 10035) lacks both transverse processes, the left anterior process and the tip of the neural spine (MWC91.6, MHC102.9, MDC114.9). The third caudal (CA3, SPQ 100-36) lacks most of the transverse processes and the tip of the neural spine, as well as lacking bone in the posteroventral part of the centrum (MWC94.4, MHC100.7, MDC104.5). The fourth caudal (CA4, SPQ 100-37) lacks the right transverse process, the anterior tip of the left transverse process and most of the left side of the neural canal (MHV208.2, MWC93.3, MHC approximately 99.6, MDC100.2). The fifth caudal (CA5, SPQ 10038) lacks most of the right transverse process, the right anterior process and the tip of the neural spine, as well as the anteriormost tip of the left transverse process (MWC90.6, MHC99.1, MDC88.8). The sixth caudal (CA6, SPQ 100-39) is slightly abraded and lacks the anterior portion of the right transverse process, most of the right anterior process and the tip of the neural spine (MWC87.3, MHC100.7, MDC77.2). The seventh caudal (CA7, SPQ 100-40) is complete (MHV148.8, MWV94.7, MWC77.2, MHC93.4, MDC70.5). The eighth caudal (CA8, SPQ 100-41) is complete (MHV134.3, MWV83.1, MWC72.0, MHC91.8, MCD66.3). The ninth caudal (CA9, SPQ 100-42) is complete (MHV121.9, MWV77.2, MWC68.4, MHC87.3, MDC63.8). The tenth caudal (CA10, SPQ 100-43) is complete (MHV106.4, MWV71.6, MWC64.2, MHC82.3, MDC58.9). The eleventh caudal (CA11, SPQ 100-44) is complete (MHV90.1, MWV66.1, MWC62.5, MHC75.1, MDC54.9). The twelfth caudal (CA12, SPQ 100-45) is complete (MHV81.0, MWV64.5, MWC60.2, MHC75.2, MDC48.5). At this point in the series, because of the smallness and simplicity of the last 10 caudal vertebrae, only maximum dimensions of width, height and depth are given. The thirteenth caudal (CA13, SPQ 100-46) is complete (MHV65.5, MWV67.3, MDV41.1). The fourteenth caudal (CA14, SPQ 100-47) is complete (MHV51.2, MWV65.6, MDV33.4). The fifteenth caudal (CA15, SPQ 100-48) is complete (MHV43.9, MWV59.8, MDV28.0). The sixteenth caudal (CA16, SPQ 100-49) is complete (MHV36.7, MWV52.9, MDV26.1). The seventeenth caudal (CA17, SPQ 100-50) is complete (MHV32.6, MWV50.5, MDV23.9). The eighteenth caudal (CA18, SPQ 100-51) is complete (MHV27.2, MWV47.3, MDV21.2). The nineteenth caudal (CA19, SPQ 100-52) is complete (MHV24.5, MWV43.3, MDV18.2). The twentieth caudal (CA20, SPQ 10053) is complete (MHV21.7, MWV39.7, MDV15.4). The twentyfirst caudal (CA21, SPQ 100-54) is complete (MHV18.2, MWV35.7, MDV14.7). The twenty-second caudal (CA22, SPQ 100-55) is complete (MHV12.6, MWV26.4, MDV13.0).

\section{Chevrons}

Ten of eleven chevrons (suspended below the adjacent ends of the anterior caudal vertebrae) are present - the posterior seven being complete (Fig. 9). They decrease in keel depth from 72.6 (CH1, SPQ 100-56) to 30.1 (CH10, SPQ 100-57).

\section{RIBS}

Ten of eleven ribs on the left side are represented. Only the first five of these are complete enough to measure. The first (LR1, SPQ 100-58) is complete (TLI265.0, MLTH90.0). The second (LR2, SPQ 100-59) is complete (TLI405.0, MLTH95.2). The third (LR3, SPQ 100-60) is complete (TLI545.0, MLTH93.6). The fourth (LR4, SPQ 100-61) is complete (TLIC635.0, MLTH92.6). The fifth (LR5, SPQ 100-62) is complete (TLIC680.0, MLTH87.7). The sixth (LR6, SPQ 10063) is nearly complete but is broken about a fifth of the way down, with no sure fit among the fragments preserved. The seventh (LR7, SPQ 100-64) lacks the distal half. The eighth (LR8, SPQ 100-65) is nearly complete but there is no sure fit for the proximal and distal ends. The ninth (LR9, SPQ 10066) lacks the anterior half of the proximal articular surface and the distal fifth of the rib. Only the distal half of the tenth (LR10, SPQ 100-67) is preserved.

Ribs on the right side are relatively poorly represented (7 of 11), and were not measured. The fourth (RR4, SPQ 10068) consists of a third of the rib near the proximal end. The fifth (RR5, SPQ 100-69) consists of the proximal fifth with articular surfaces for vertebrae. The sixth (RR6, SPQ 100-70) is represented by the proximal end with facets for articulation with the vertebrae. The seventh (RR7, SPQ 100-71) consists of the proximal quarter lacking articular facets for the vertebrae. The eighth (RR8, SPQ 100-72) is represented by the proximal half of the rib with most of the articular facets. The tenth (RR10, SPQ 100-73) lacks the distal half. The eleventh (RR11, SPQ 100-74) consists of the proximal third with incom-

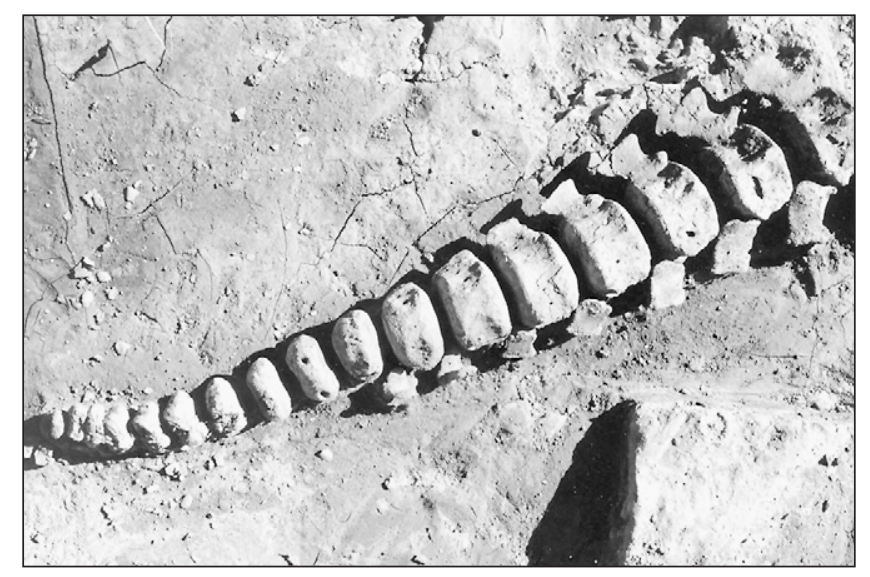

FIGURE 9. Sequence of caudal vertebrae as excavated extending toward tip of tail at left showing seven chevrons below.

Vue au cours des fouilles de la séquence des vertèbres caudales qui s'étend jusqu'à l'extrémité de la queue et qui montre à gauche sept chevrons. 
pletely preserved articular surfaces for the vertebrae. Probably the fact that the whale came to rest on its left side accounts for the difference in preservation, because the right side was exposed slightly longer before burial in sediment, thus allowing for quicker deterioration.

\section{STERNUM}

The sternum (S1, SPQ 100-75) is complete, having articular facets for six sternal ribs on each side (ML450.0, MLN385.0, MW198.3).

\section{STERNAL RIBS}

Most are preserved, but in fragments. The only complete ones are: left first (LSR1, SPQ 100-76) (ML207.6); left fourth (LSR4, SPQ 100-77) (ML235.0); left sixth (LSR6, SPQ 10078) (ML288.4); left seventh (LSR7, SPQ 100-79) (ML127.1); right first (RSR1, SPQ 100-80) (ML205.5); right second (RSR2, SPQ 100-81) (ML183.8); right fourth (RSR4, SPQ 100-82) (ML229.8); right sixth (RSR6, SPQ 100-83) (ML287.8).

\section{FORELIMBS}

The left forelimb is nearly complete (Fig. 10). The left scapula (LS1, SPQ 100-84) is complete except for damage to the dorsal margin (MAL402.0, MAN102.7, LGC68.5, MWGC55.1, MHS254.3). The left humerus (LH1, SPQ 100-85) is complete (MH152.2, MPL66.3, MPD82.1, MMW40.6, MMD37.6, MDL79.0, MDD42.4). The left radius (LR1, SPQ 100-86) is complete (MH119.0, MPL45.4, MPD37.4, MDL72.0, MD29.3). The left ulna (LU1, SPQ 100-87) is complete (MH111.0, MPL50.5, MPD37.1, MSL26.2, MSD22.8, MDL53.5, MDD28.8). The left manus (LM1, SPQ 100-88) is less complete than the right with two proximal carpals, four distal carpals, digit I is lacking, digit II has LD2-1 and LD2-4, digit III has LD3-1 to LD3-4, digit IV has LD4-1 and LD4-2, digit V has LD5-1 and LD5-2.

The right forelimb is nearly complete. Only the base of the right scapula (RS1, SPQ 100-89) is preserved, including the two anterior processes and the proximal two-thirds of the posteroventral margin of the blade (MLN112.9, LGC69.8, MWGC55.2). The right humerus (RH1, SPQ 100-90) is complete (MH152.6, MPL67.6, MPD83.3, MML40.6, MMD40.2, MDL76.8, MDD45.1). There is a deep pit below the posterior margins of the head that appears to be pathological - and suggestive of an old individual. The exosteal roughness of the lateral surfaces of both humeri below the ball joints is also pathological and indicative of an old animal. The right radius (RR1, SPQ 100-91) is complete (MH120.1, MPL47.0, MDL72.9, MDD30.7). The right ulna (RU1, SPQ 100-92) is complete (MH112.6, MPL48.6, MPD37.7, MSL26.1, MSD22.8, MDL56.4, MDD28.3). The right manus (RM1, SPQ 100-93) is nearly complete with two proximal carpals, five distal carpals, digit I has RD1-1 and RD1-2, digit II has RD2-1 to RD2-4, digit III has RD3-1 to RD3-4, digit IV has RD4-1 to RD4-3, digit V has RD5-1 to RD5-3.

\section{PELVIS}

A vestige of the pelvis (P1, SPQ 100-94) is represented.

\section{BURIAL POSITION}

The body of Félix lay on its left side on a horizontal plane (the most common position for a beached whale carcass) with its long axis oriented NW-SE, paralleling the ditch excavated by the backhoe (Fig. 8). The cranium lay mainly on its dorsal surface, clearly exposing the palatal region. White whales have a flexible neck, the cervical vertebrae being unfused, which accounts for the head being extended obliquely. The mandible was intact and articulated naturally with the cranium. Most teeth were found in place in the upper and lower jaws. The hyoid apparatus is intact and was in natural position. The auditory bullae were slightly separated from the cranium, each being found on its appropriate side. Cervical and thoracic vertebrae were naturally articulated, and the ribs, as originally found, were in good condition and in proper order. Similarly, the sternal ribs were articulated with the sternum which lay with its ventral surface upward. The forelimbs were almost completely preserved. The underside (left) one is noteworthy, being fully articulated (Fig. 10) and better preserved than the right one, where some digits were found separated but near the ribcage. Originally the rather fragile scapulae were well preserved and articulated with the humeri. The vestigial bone of the pelvis was found in appropriate anatomical position and near the vertebral column. The chevron bones were naturally articulated with the caudal vertebrae (Fig. 9).

\section{TAPHONOMY}

Little is known about how marine mammals become fossils. Most die at sea, and close examination of the processes of decay, dismemberment, alteration, transport and burial of carcasses after death is rare (Liebig et al., 2003). However, Schäfer's (1972) study of decaying remains of whales along

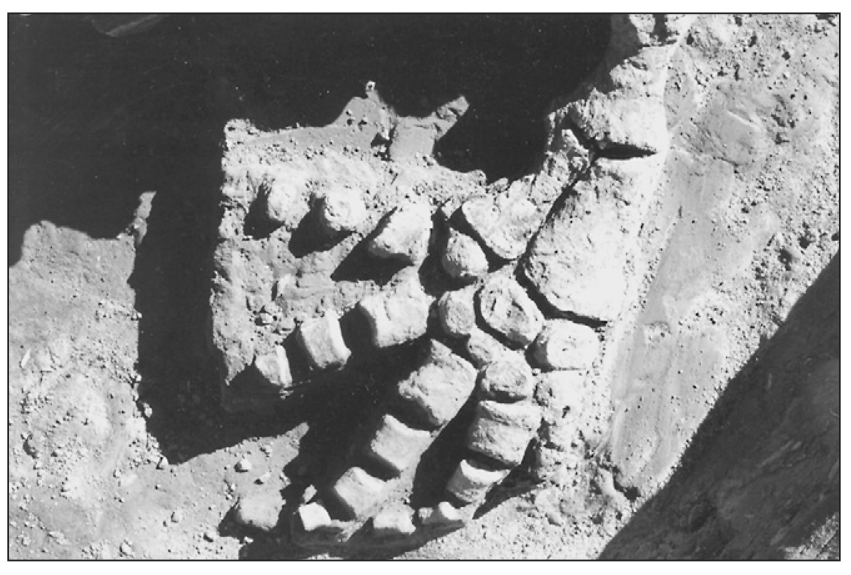

FIGURE 10. Left forelimb as excavated showing (from top to bottom) humerus, radius, ulna, metacarpals, digits.

Vue au cours des fouilles de la nageoire gauche, montrant (de haut en bas) l'humérus, le radius, le cubitus, les métacarpes et les doigts. 
the North Sea coast is perhaps the closest modern analogue to the Champlain Sea environment and the case of Félix. White whales are commonly found in shallow water, river mouths and estuaries of the Arctic today; situations similar to that of Félix. Also, it is worth noting that if a whale dies in a small ocean basin (like the Champlain Sea), the floating carcass can be easily transported to a beach before it disintegrates. Rarely is a whole carcass buried quickly enough so that the skeleton remains intact. Indeed Schäfer (1972) suggests there are only two ways in which complete vertebrate skeletons can be preserved: (1) by quick burial in zones of rapid sedimentation; (2) by burial in a place sheltered from currents that would help to conserve the bones. Furthermore, only bloated carcasses buried under those conditions would remain intact. If the carcass were buried after the gas had escaped, then it would likely suffer distortion.

Observation of the skeleton of Félix leads us to believe that the bloated carcass was: (1) washed up on a northern beach of the Champlain Sea - probably by southerly winds, if it had not died near the beach; (2) that it came to rest on its left side, oriented in a NW-SE direction - probably nearly parallel to the beach; (3) that it was quickly buried by sediment (oxygen-poor impermeable clays) - perhaps within a few weeks, noting that skulls of stranded seal carcasses are broken up and their neck vertebrae scattered after 44 days (Schäfer, 1972).

There was no evidence of damage by predators or scavengers, nor bioturbation by invertebrates in the matrix surrounding Félix. It is interesting to note that the interior of the cranium of Félix was not filled by sediment - again suggesting that the presence of brain matter precluded entry by sediments during rapid burial. A crack present in the mandible, and on several ribs, is attributed to compression by overlying sediments. Moreover, there were no signs that the bones had been exposed to much weathering, sand blasting on a beach, or abrasion by tidal transport. Certainly the matrix surrounding Félix lacks sedimentary structures indicative of high energy water currents, and sediment grain-size is small, again suggesting quiet water deposition. Compaction of mud and silts around the skeleton may have helped to protect it from exposure to later erosion. In any case, it is worth examining the paleogeography of the fossil site and rates of sedimentation for that region some $13000\left(11000{ }^{14} \mathrm{C} \mathrm{BP}\right)$ years ago.

\section{PALEOGEOGRAPHY: THE L'ASSOMPTION RIVER PALEODELTA}

In the northern part of the Champlain Sea near the edge of the Laurentian Plateau, deltas and beaches formed at the mouths of tributary valleys and in shallow waters of the paramarine lacustrine basin. Suspended sediments, mainly siltyclay, were deposited there (Denis and Prichonnet, 1973; LaSalle and Elson, 1975; Prichonnet, 1977).

A well-developed paleodelta was built at the mouth of l'Assomption River, $4 \mathrm{~km}$ west of the fossil locality (Fig. 2). Features of the deltaic front are well exposed near Saint-Félixde-Valois. The finer suspended load of this river was carried farther into the shallow waters of the basin where it overlay
Champlain Sea clays, forming a subaqueous sloping bar (Denis and Prichonnet, 1973). The paleodelta spread laterally, with a gentle eastward slope, at elevations of 160, 150 and $140 \mathrm{~m}$. The fossil locality lies near the base of the eastern side of a small hill and at the eastern extension of the delta, which was mainly built of fine sediment.

From the study of the Saint-Césaire section in the central part of the Champlain Sea, de Vernal et al. (1989) have suggested low sedimentary accumulation rates of the order of $1 \mathrm{~mm} / \mathrm{yr}$. However, Félix is too well preserved for such a slow rate of accumulation. In the fiords and tributary rivers in the northern part of the marine basin, rates were probably much higher. Parent and Occhietti (1988: p. 238) state that for Phase III of the Champlain Sea following the Saint-Narcisse episode (10 800-9300 ${ }^{14} \mathrm{C} \mathrm{BP}$ ) "North of the Saint-Narcisse Moraine, sedimentation rates were high, ranging from 9 to $18 \mathrm{~cm}$ per (radiocarbon) year. At the mouth of the Saint-Joseph-deMékinac paramarine basin, single layers in basal rhythmites are up to $20 \mathrm{~cm}$ thick. In the fiord-like valley of the middle Saint-Maurice River... $57 \mathrm{~m}$ of silt and sand were deposited during an interval lasting from 300 to 500 years. In the Shawinigan Embayment... marine clay and silts commonly reach thicknesses on the order of 30 to $60 \mathrm{~m}$ and were deposited in a few estuaries between approximately 10.8 and $10 \mathrm{ka}{ }^{14} \mathrm{C} \mathrm{BP}$, at an average sedimentation rate of $7.5 \mathrm{~cm}$ per (radiocarbon) year".

We hypothesize that the main source of rapid sedimentation and accumulation was the l'Assomption River paleodelta itself. Quick deglaciation following construction of the SaintNarcisse Moraine presumably would have discharged large amounts of meltwater and sediments into the basin.

Unfortunately, a precise chronology of events relative to the l'Assomption paleodelta is not yet established. In any case, delta deposition can be very rapid, discharge being highly seasonal and variable annually. Furthermore, geological evidence indicates that the fossil site was near the delta outwash, so it is plausible to suggest that Félix was rapidly covered by this discharge.

\section{PALEOENVIRONMENT}

\section{BACKGROUND}

Stratigraphic relationships of fossil microorganisms such as dinocysts, pollen grains, pteridophyte spores and organic linings of benthic foraminifers (Fig. 11) present an opportunity to learn more about Champlain Sea paleoenvironments in the Saint-Félix-de-Valois region, including sea-surface conditions, when Félix died (de Vernal et al., 1989, 2001). Dinocyst assemblages were used to help reconstruct sea-surface conditions based on the modern analogue technique. Palynological analyses were conducted also on terrestrial flora to document the input from the vegetation and to establish correlation with the terrestrial palynostratigraphy. 


\section{METHODS}

\section{Sampling}

Sediment samples were taken at $2 \mathrm{~cm}$ intervals from bottom to top after the surface at the exposure was cleaned with a trowel. All samples were taken with Teflon instruments and cleaned after each sampling to avoid contamination. The first five samples (A1 to A5) were taken from unit 1 at 5-cm intervals. Samples A6 to A13 were taken from unit 2. Only three samples (A14 to A16) were taken at $10-\mathrm{cm}$ intervals from unit 3 beginning at the base. Because the upper portion of this unit had been disturbed, further samples were not taken. Then a backhoe was used to expose the basal unit (unit 1) to a depth of $320 \mathrm{~cm}$ for further sampling, and six samples (B1 to B6) were taken at $30-\mathrm{cm}$ intervals between the 320 and $170 \mathrm{~cm}$ levels.

\section{Processing}

Wet and dry weights were recorded for each $5 \mathrm{~cm}^{3}$ sample. Sieving at $106 \mu \mathrm{m}$ and $10 \mu \mathrm{m}$ eliminated all coarse $(>106 \mu \mathrm{m})$ and fine $(10 \mu \mathrm{m})$ particles. Lycopodium spores in calibrated tablets were added to each sample. The 106-10 $\mu \mathrm{m}$ fraction was treated with $10 \%$ hydrochloric acid and $49 \%$ hydrofluoric acid to dissolve calcium carbonate and silica particles. Residues of this treatment were washed and screened for a second time at $10 \mu \mathrm{m}$ and fixed on slides with glycerine jelly.

\section{Counting}

The coarse fraction $(>106 \mu \mathrm{m})$ was examined under a binocular microscope for larger fossils (e.g., marine mollusk shells and foraminifer tests). The fraction between 106 and $10 \mu \mathrm{m}$ was examined under an optical microscope at 400 to 1000 magnification, using transmitted-light to count all identifiable palynomorphs. They include organic foraminifer linings, dinocysts, pollen grains and spores. Pollen grains and dinocysts were identified to species or genus levels and counted to reach sums of 300 for each. Concentrations of palynomorphs per dry weight of sediment were calculated based on the relative number of Lycopodium spore markers.

\section{Paleoenvironmental reconstructions}

The best modern analogue method was used to quantitatively reconstruct paleoenvironmental conditions (de Vernal et al., 2001) based on the updated modern dinocyst database that includes the percentages of 60 taxa at more than 940 reference sites from middle to polar latitudes of the northern hemisphere (de Vernal et al., 2005).

\section{PALYNOLOGICAL DATA AND INTERPRETATION}

\section{Palynomorphs of terrestrial origin}

The assemblage presents a co-dominance of arboreal [pine and spruce (Pinus and Picea)], and shrub [birch and alder (Betula and Alnus)] pollen together with moss (Sphagnum) spores. The pollen assemblages suggest a regional shrub-tundra to forest-tundra plantscape (Fig. 12). Due to the differential hydrodynamic and aerodynamic properties of pollen and spores, the representation of various pollen taxa can be distorted (de Vernal et al., 1989). Compared to angiosperms, gymnosperms are favoured because their pollen is produced in very large quantities and can travel long distances. The arboreal pollen in the Champlain Sea sediments is possibly a representation of the vegetation hundreds of kilometres from the study site. On the other hand, angiosperms, generally transported by nearby hydrographic networks, represent vegetation closer to the Champlain Sea.

The stratigraphic sequence reveals, from its base upward, a changing paleogeography as indicated by decreasing concentration of pollen, and an increase in percentage of shrub (birch and alder) pollen compared to arboreal (pine and

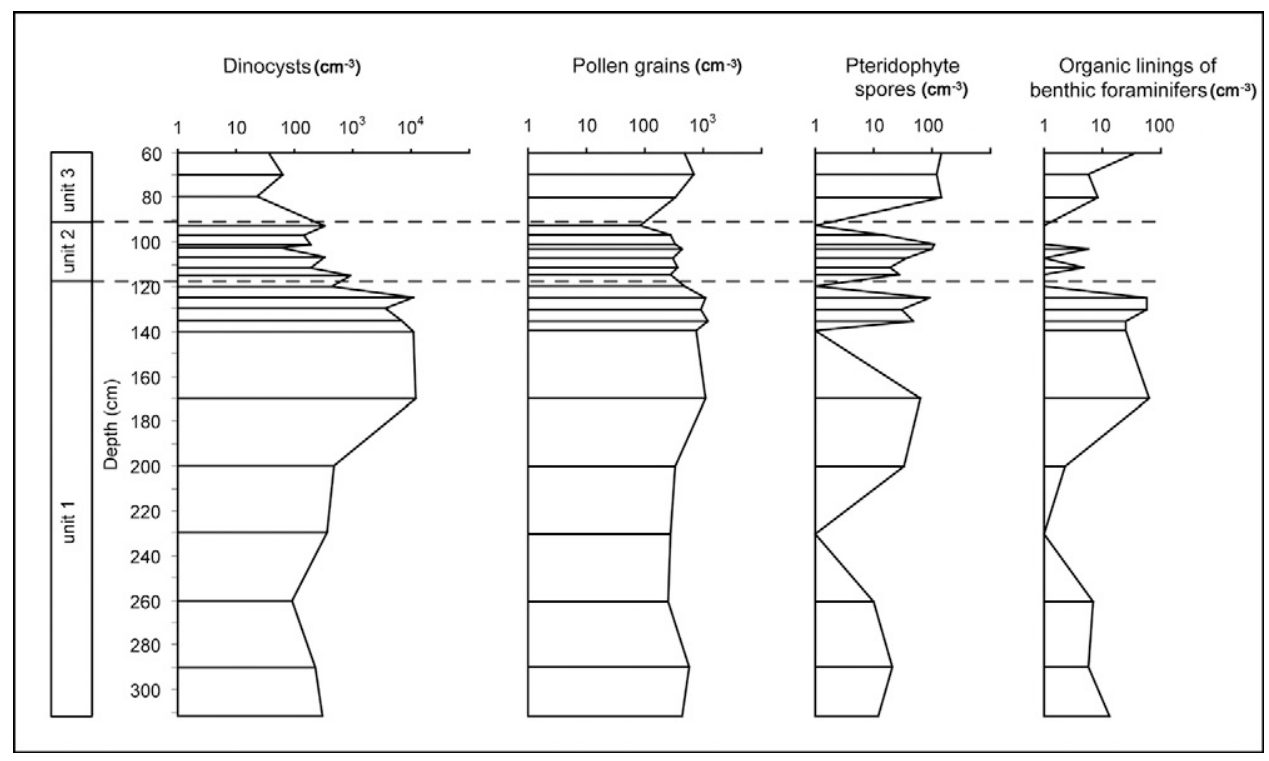

FIGURE 11. Stratigraphic diagram at the Saint-Félix-de-Valois fossil locality showing concentrations of dinocysts, pollen grains, spores of pteridophytes and organic foraminifer linings. Note particularly the values in unit 2 (outlined by horizontal dashed lines) which contained Félix.

Concentrations des dinokystes, des grains de pollen, des spores de ptéridophytes et des foraminifères organiques dans la coupe stratigraphique de la localité fossile à Saint-Félix-de-Valois. II faut noter en particulier les valeurs de l'unité 2 (lignes horizontales pointillées) dans laquelle Félix a été découvert. 
spruce) pollen . The pollen at the bottom of the section is mainly from gymnosperms, with proportions ranging from 15$60 \%$, and $5-30 \%$, for Pinus and Picea, respespectively. Toward the top of the section their proportions are reduced by almost half. Nearer the top of the section, angiosperm (birch and alder) pollen dominates. Birch pollen increases from about $10 \%$ at the bottom of the section to more than $30 \%$ at the top. Alder pollen goes from less than $10 \%$ at the bottom to more than $20 \%$ at the top of the section.

\section{Marine palynomorphs}

Foraminifers and organic linings. No foraminiferal tests were observed in the $>106 \mu \mathrm{m}$ fraction. However, foraminiferal organic linings were found on the microscope slides with concentrations of up to $50 \mathrm{specimens} / \mathrm{g}$. This indicates that foraminifers were present, but due to the dissolution of carbonates, no calcareous tests were preserved (de Vernal et al., 1992).

Dinocysts. Low taxonomic diversity (10 taxa) characterizes the dinocyst assemblages (Fig. 13). The dominant taxa are Operculodinium centrocarpum, Brigantedinium spp., Islandinium minutum, and Islandinium cf. cezare. Operculodinium centrocarpum is found in all samples from the Saint-Félix-de-Valois site and dominates most samples in the upper part of the section. Several Operculodinium centrocarpum morphotypes were observed: the short-process variety and few specimens of the Arctic morphotype (de Vernal et al., 2001), which is characterized by rare and poorly-devel- oped processes. Operculodinium centrocarpum is a ubiquitous species that can tolerate cool to Arctic surroundings (Rochon et al., 1999; de Vernal et al., 2001). In modern assemblages in Baffin Bay, where sea surface salinity is about 32, it is the predominant taxon (Mudie and Short, 1985). This taxon increases from 5 to almost $80 \%$ from bottom to top of the stratigraphic sequence at Saint-Félix-de-Valois. Brigantedinium is another ubiquitous taxon (Rochon et al., 1999). It varies from $90 \%$ at the bottom of the section to less than $5 \%$ at the top. Islandinium, which is common in Arctic and subarctic environments (Head et al., 2001), declines from $20 \%$ at the bottom of the section to less than $5 \%$ at the top.

Two distinct types of environment are reflected in these analyses. Zone 1 Assemblage characterizes the base of the stratigraphic section. Brigantedinium spp., Islandinium minutum and Islandinium cf. cezare, which are all linked to heterotrophic productivity, dominate the assemblage. The significant occurrence of Islandinium and the very low diversity of species suggest a very cold and low salinity environment. The dinocyst concentration is relatively low (about 500 individuals per g), and the Brigantedinium proportions vary between 50 and $90 \%$. The best analogue technique reveals similarities with spectra from the Canadian Arctic, and suggests summer sea-surface temperatures between $-1^{\circ} \mathrm{C}$ and $2{ }^{\circ} \mathrm{C}$ and a surface salinity of 30 to 31 , with sea ice present for about 10 months per year.

Zone 2 Assemblage is largely dominated by Operculodinium centrocarpum, which is an autotrophic species. The change in assemblage from Zone 1 to Zone 2 is

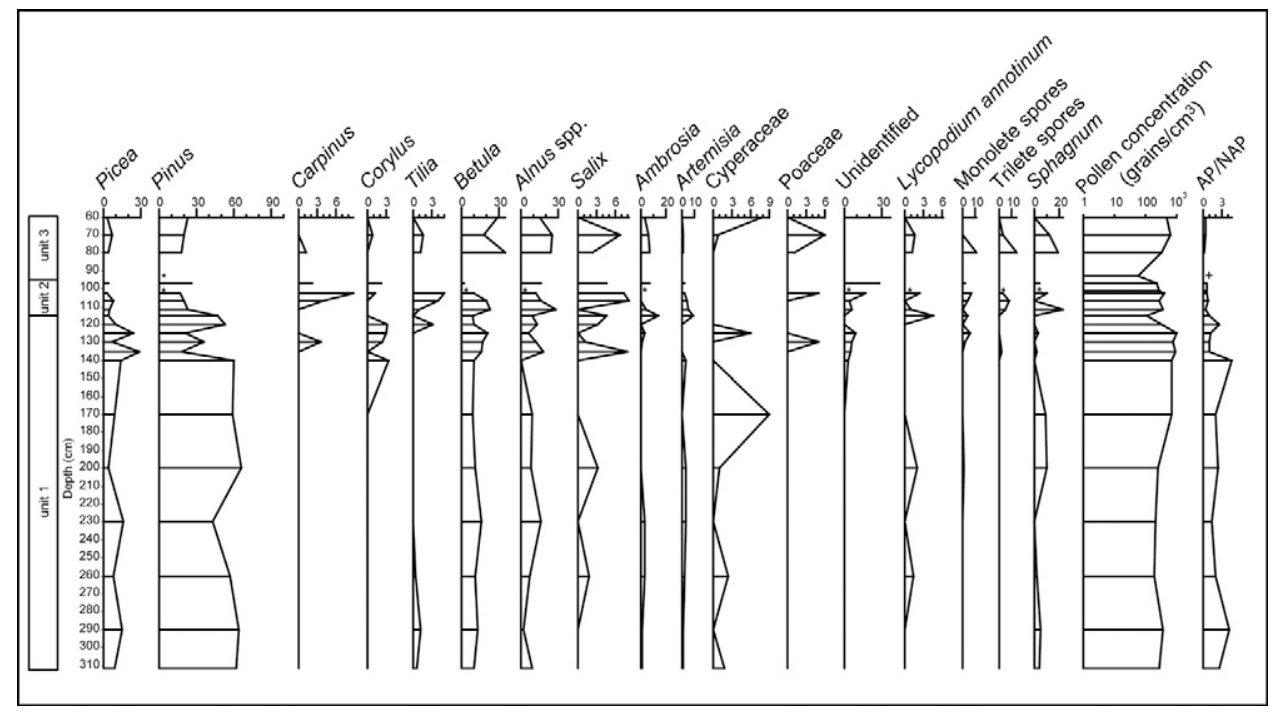

FIGURE 12. Stratigraphic diagram at the Saint-Félix-de-Valois fossil locality showing percentages of pollen and spores found at various levels through the section. AP/NAP shows percentages of arboreal pollen to those of non-arboreal pollen (shrub and herbs). The + sign on the AP/NAP curve indicates an absence of arboreal pollen. The asterisks indicate the presence in various taxa of samples having less than 20 pollen grains counted, therefore not permitting calculation of percentages. Concentration of pollen at each level is expressed in number of specimens per $\mathrm{cm}^{3}$. Note that scales are different for the various profiles.
Pourcentages de pollen et de spores trouvés à différents niveaux de la séquence stratigraphique de la localité fossile à Saint-Félix-deValois. Le profil AP/NAP indique les pourcentages de pollen arboréen par rapport au pollen non-arboréen (arbustes et herbacés). Le symbole "+" du profil AP/NAP indique l'absence de pollen arboréen. Les astérisques indiquent la présence de taxons variés dans les échantillons qui ont moins de vingt grains de pollen et qui ne permettent pas le calcul des pourcentages. La concentration du pollen à chaque niveau est exprimée en nombre de spécimens par $\mathrm{cm}^{3}$. II faut noter que les échelles sont différentes pour les divers profils. 
marked by an increase in dinocyst concentration of one order of magnitude, up to 10000 dinocysts per $\mathrm{g}$. It probably represents a change toward warmer conditions. The quantitative reconstruction of sea-surface temperature suggests a slight warming (up to $4^{\circ} \mathrm{C}$ in summer) and a slight decrease in seaice cover.

\section{Paleoenvironmental reconstructions and comparisons}

Reconstructions of Champlain Sea surface conditions based on a study of dinocysts (Fig. 14) indicate an environmental transition from cold to cool temperature [see limit at a depth of $185 \mathrm{~cm}$ (Figs. 13-14)].

\section{CONCLUSIONS}

(1) A nearly (approximately 95\%) complete skeleton of an old, probably male, white whale (or beluga) was excavated from Champlain Sea deposits at Saint-Félix-de-Valois, Québec in 2001.

(2) It is the best preserved of 21 white whale specimens known from the Champlain Sea, and has yielded a radiocarbon date of $10700 \pm 90{ }^{14} \mathrm{C} \mathrm{BP}$ (TO-9996).

(3) Most of the skeleton was embedded in a wet silty clay unit, the surrounding matrix containing shells of Mya arenaria,
Hiatella arctica and Mytilus edulis, as well as a starfish such as Ophiura. This assemblage compares well with Cronin's (1977) Mya phase fauna (11600-10 $\left.600{ }^{14} \mathrm{C} \mathrm{BP}\right)$, which is in accord with the radiocarbon age of Félix.

(4) Observation of the skeleton and its surrounding sediment indicate that the carcass was washed up on a northern beach of the Champlain Sea; that it came to rest on its left side, oriented NW-SE — probably nearly parallel to the beach; and that it was quickly buried in oxygen-poor impermeable clays.

(5) We hypothesize that the main source of rapid sedimentation and accumulation affecting the burial of Félix was the l'Assomption River paleodelta, which lay $4 \mathrm{~km}$ west of the fossil locality.

(6) Various palynomorphs indicate a change from cold to cool conditions before $10700{ }^{14} \mathrm{C} \mathrm{BP}$ (i.e., at a depth of about $185 \mathrm{~cm}$ in the section at the fossil site - some $70 \mathrm{~cm}$ below the base of unit 2 where Félix lay).

\section{ACKNOWLEDGEMENTS}

We are particularly grateful to Monique Héneault (SaintFélix-de-Valois), not only for her curiosity and astuteness in trying to identify the fossil, but also for permission to excavate the skeleton on her land. We also thank: Dr. David Sergeant for

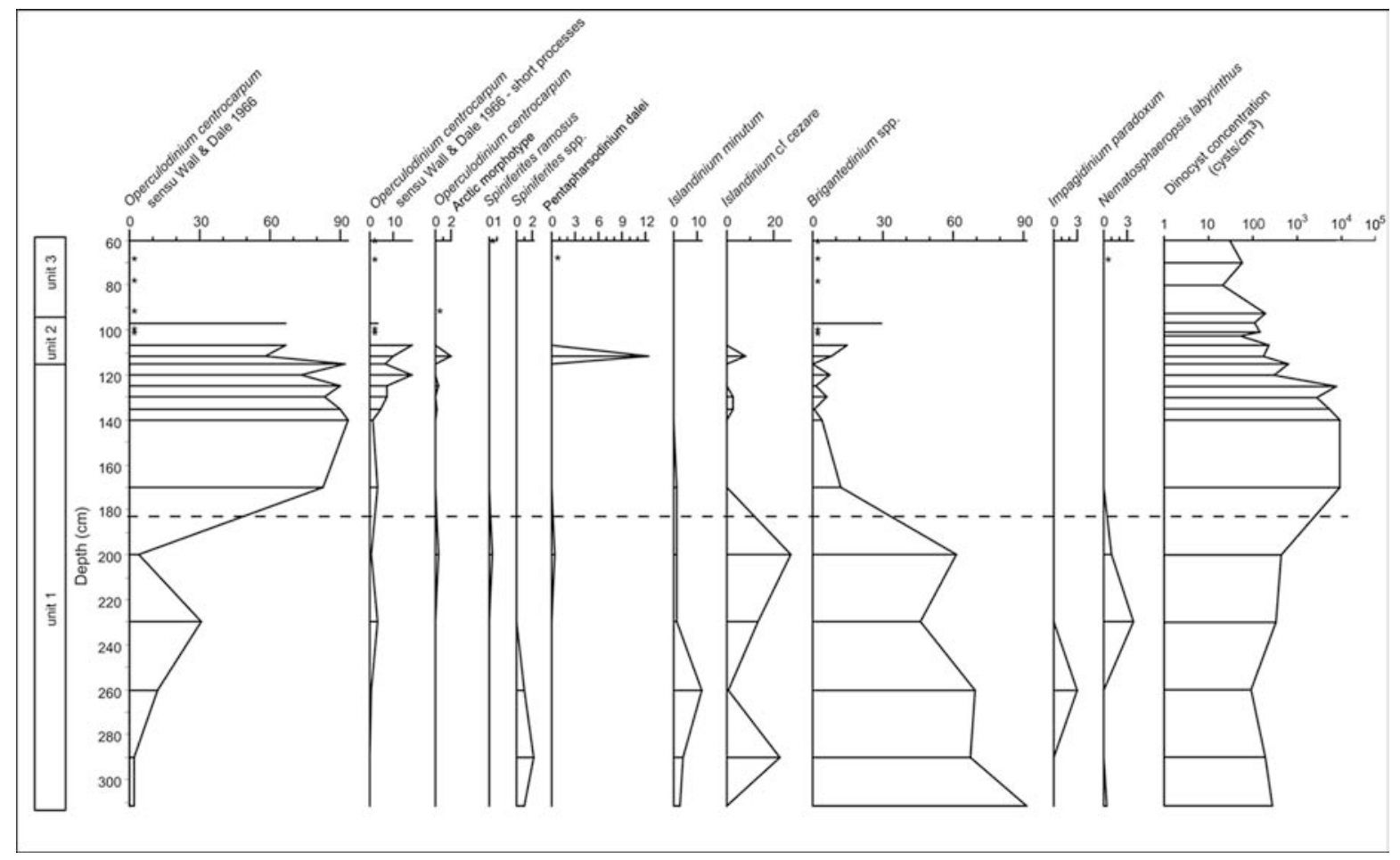

FIGURE 13. Stratigraphic diagram at the Saint-Félix-de-Valois fossil locality showing the percentage and concentration of dinocyst taxa at various levels through the section. Asterisks indicate the presence of taxa in samples having less than 20 dinocysts counted (therefore insufficient for calculating percentages). The dashed line marks a transition in the assemblage that suggests a major change in the aquatic environment. Note that scales are different for the various profiles.
Pourcentages et concentrations de taxons de dinokystes dans les différents niveaux de la coupe stratigraphique de la localité fossile à Saint-Félix-de-Valois. Les astérisques indiquent la présence de taxons dans les échantillons qui sont inférieurs à vingt (insuffisant pour calculer les pourcentages). La ligne pointillée marque une transition qui suggère un changement important dans l'environnement aquatique. Notez les échelles différentes pour les divers profils. 


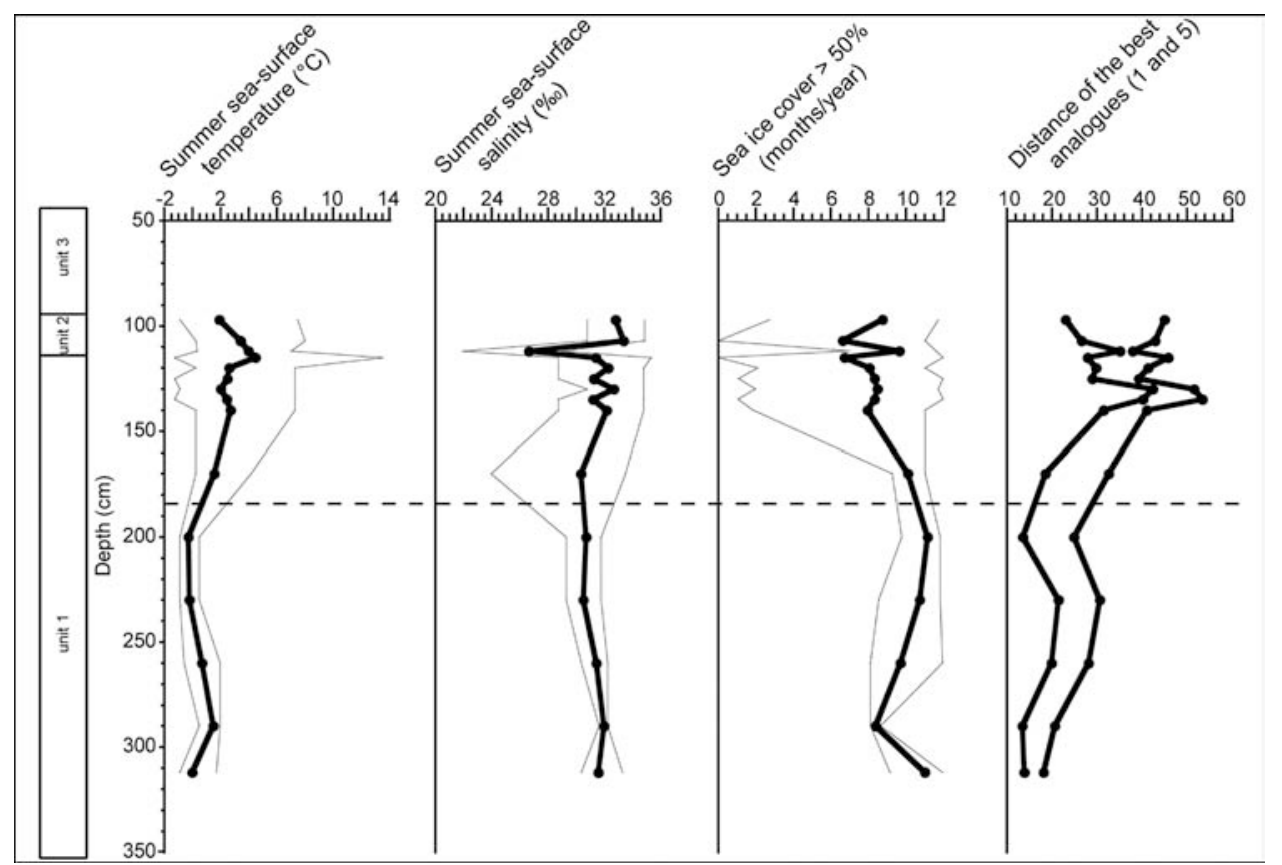

FIGURE 14. Reconstruction of the sea-surface conditions at the Saint-Félix-de-Valois fossil locality based on dinocyst assemblages. The thick line corresponds to the most probable value as calculated from the weighted average of the instrumental values for the five best analogues. The thin lines correspond to the minimum and maximum possible on the basis of the five best modern analogues. The distance of the fossil spectra from modern analogues is shown at the right. It indicates a good analogue situation inasmuch as it is lower than the threshold value of 76.4 (de Vernal et al., 2005). The dashed line corresponds to the change in assemblages as illustrated in Figure 13.

his estimate of the individual age of Félix based on a microscopic examination of a tooth section; Dr. Veronique Lesage (Fisheries and Oceans Canada, Mont Joli) for information on the lifespan of white whales; George Mrazek (University of Ottawa) for sectioning the tooth; Gilles Baril (Québec deputy in Berthier) for financially supporting radiocarbon analysis of Félix; Eric Perrault for assistance in excavating Félix; Pierre Desmarais for providing information on the geological setting of the fossil and for confirming marine mollusk shell identifications; Ingrid Birker for estimating the completeness of two Champlain Sea white whale skeletons from Montréal in the Redpath Museum collections; members of the Société de Paléontologie du Québec for information and technical support, especially Gilbert Pauzé, Jean-Claude Duclos, JeanFrançois Léonard and François Quintal; Alwynne Beaudoin (Associate Editor), Martin Head and Paul Matheus for their constructive comments which helped to improve the paper. Gail Harington kindly word-processed the manuscript and assisted with the figures.

"We sincerely regret the untimely death of our colleague Maxime Paiement, to whom this paper is fondly dedicated".

$$
\text { C.R. Harington, S. Lebel and A. de Vernal }
$$

"He was a really nice young fellow; I had him as a student in one of my seminars, and he was a most
Reconstitution des conditions des eaux de surface basée sur les assemblages de dinokystes à la localité fossile de Saint-Félix-deValois. La ligne noire en gras correspond à la valeur la plus probable calculée à partir de la moyenne des valeurs pour les cinq meilleurs analogues. Les lignes plus fines correspondent aux minimum et maximum présumés sur la base des cinq meilleurs analogues modernes. La distance du spectre fossile par rapport aux analogues modernes est indiquée à droite. Elle suggère une situation de bon analogue lorsqu'elle est plus basse que le seuil de 76,4 (de Vernal et al., 2005). La ligne pointillée correspond au changement dans les assemblages tel qu'illustré à la figure 13.

pleasant and dedicated participant. He also worked on the marine microfossils in the bottommost sediment cores of Lake Hertel (Mont Saint-Hilaire), one of my favorite sites those days. We had interesting discussions on the significance of the results on Dinoflagellate cysts, and I think he was about to finish his M.Sc. degree on Champlain Sea deposits when the accident happened (Maxime Paiement passed away on August 18th, due to a fatal head injury from a rockfall during a climb)".

P.J.H. Richard

\section{REFERENCES}

Ardley, E., 1916. Note on the discovery of a skeleton of Beluga catodon (white whale) in the Pleistocene (Leda clay) at the town of Montreal East, Quebec. Canadian Record of Science, 9: 490-493.

Berta, A., Sumich, J.L. and Kovacs, K.M., 2006. Marine Mammals: Evolutionary Biology. $2^{\text {nd }}$ edition. Elsevier, Amsterdam, $547 \mathrm{p}$.

Billings, E., 1870. Bones of a whale lately discovered at Cornwall, Ontario. Canadian Naturalist and Quarterly Journal of Science (New Series), 5: 438439.

Bouchard, M.A., Harington, C.R. and Guilbault, J.-P., 1993. First evidence of walrus (Odobenus rosmarus L.) in Late Pleistocene Champlain Sea sediments, Quebec. Canadian Journal of Earth Sciences, 30: 1715-1719.

Brodie, P.F., 1989. The white whale Delphinapterus leucas (Pallas, 1776), p. 119144. In S.H. Ridgway and R. Harrison, eds., Handbook of Marine Mammals, Vol. 4. Academic Press, London. 
Cronin, T.M., 1977. Champlain Sea Foraminifera and Ostracoda: A systematic and paleoecological synthesis. Géographie physique et Quaternaire, 31: 107-122.

Dawson, J.W., 1895. Note on a specimen of Beluga catodon, from the Leda clay, Montreal. Canadian Record of Science, 6: 351-354.

Denis, R. and Prichonnet, G., 1973. Aspects du Quaternaire dans la région au nord de Joliette. Livret guide d'excursion, 2e colloque du Quaternaire du Québec, Montréal, 60 p.

de Vernal, A., Goyette, C. and Rodrigues, C.G., 1989. Contribution palynostratigraphique (dinokystes, pollen et spores) à la connaissance de la mer de Champlain: coupe de Saint-Césaire, Québec. Canadian Journal of Earth Sciences, 26: 2450-2464

de Vernal, A., Bilodeau, G., Hillaire-Marcel, C. and Kassou, N., 1992. Quantitative assessment of carbonate dissolution in marine sediments from foraminifer linings vs. shell ratios: Example from Davis Strait, NW North Atlantic. Geology, 20: 527-530.

de Vernal, A., Eynaud, F., Henry, M., Hillaire-Marcel, C., Londeix, L., Mangin, S., Matthiessen, J., Marret, F., Radi, T., Rochon, A., Solignac, S. and Turon, J.-L., 2005. Reconstruction of sea-surface conditions at middle to high latitudes of the Northern Hemisphere during the Last Glacial Maximum (LGM) based on dinoflagellate cyst assemblages. Quaternary Science Reviews, 24: 897-924.

de Vernal, A., Henry, M., Matthiessen, J., Mudie, P.J., Rochon, A., Boessenkool, K., Eynaud, F., Grøsfjeld, K., Guiot, J., Hamel, D., Harland, R., Head, M.J., Kunz-Pirrung, M., Levac, E., Loucheur, V., Peyron, O., Pospelova, V., Radi, T., Turon, J.-L. and Vononina, E., 2001. Dinoflagellate cyst assemblages as tracers of sea-surface conditions in the northern North Atlantic, Arctic and sub-Arctic seas: The new " $n=677$ " database and application for quantitative paleoceanographical reconstruction. Journal of Quaternary Science, 16: 681-699.

Dyke, A.S., Hooper, J., Harington, C.R. and Savelle, J.M., 1999. The Late Wisconsinan and Holocene record of walrus (Odobenus rosmarus) from North America: A review with new data from Arctic and Atlantic Canada. Arctic, 52: 160-181

Elson, J.A., 1988. The Champlain Sea: Evolution of concepts and bibliography, p. 1-13. In N.R. Gadd, ed., The Late Quaternary Development of the Champlain Sea Basin. Geological Association of Canada, St. John's, Special Paper 35, $213 \mathrm{p}$.

Folkens, P.A., Reeves, R.R., Stewart, B.S., Clapham, P.J. and Powell, J.A., 2002. Beluga, p. 318-321. In National Audubon Guide to Marine Mammals of the World. Alfred A. Knopf, New York.

Hall, E.R., 1981. The Mammals of North America. John Wiley and Sons, New York, $1181 \mathrm{p}$

Harington, C.R., 1977. Marine mammals of the Champlain Sea and the Great Lakes. Annals of the New York Academy of Sciences, 288: 508-537.

Harington, C.R., 1978. Quaternary vertebrate faunas of Canada and Alaska and their suggested chronological sequence. Syllogeus, 15: 1-105.

Harington, C.R., 1988. Marine mammals of the Champlain Sea, and the problem of whales in Michigan, p. 225-240. In N.R. Gadd, ed., The Late Quaternary Development of the Champlain Sea Basin. Geological Association of Canada, St. John's, Special Paper 35, $312 \mathrm{p}$

Harington, C.R., 2003a. Annotated Bibliography of Quaternary Vertebrates of Northern North America-with Radiocarbon Dates. University of Toronto Press, Toronto, $539 \mathrm{p}$.

Harington, C.R., 2003b. Quaternary vertebrates of Québec: A summary. Géographie physique et Quaternaire, 57: 85-94.

Harington, C.R. and Occhietti, S., 1988. Inventaire systématique et paléoécologique des mammifères marins de la Mer de Champlain (fin du Wisconsinien) et des ses voies d'accès. Géographie physique et Quaternaire, 42: 45-64.

Harington, C.R., Anderson, T.W. and Rodrigues, C.G., 1993. Pleistocene walrus (Odobenus rosmarus) from Forteau, Labrador. Géographie physique et Quaternaire, 47: 111-118.
Head, M.J., Harland, R. and Matthiessen, J., 2001. Cold marine indicators of the late Quaternary: The new dinoflagellate cyst genus Islandinium and related morphotypes. Journal of Quaternary Science, 16: 621-636.

Kalm, P., 1749. Fort Saint-Frédéric, mercredi 28 juin-9 juillet, p. 112-113. In Voyage de Pehr (sic) Kalm au Canada en 1749. Pierre Tesseyre, Montréal (annotated French translation of the travel journal by J. Rousseau and G. Béthane, Pierre Morisset, ed.).

Kovacs, K., 2005. Beluga (white) whale, p. 228-230. In M. Nuttall, ed. Encyclopedia of the Arctic. Routledge, New York.

LaSalle, P. and Elson, J.A., 1975. Emplacement of the St. Narcisse Moraine as a climatic event in Eastern Canada. Quaternary Research, 5: 621-625.

Liebig, P.M., Ta-Shana, A.T. and Flessa, K.W., 2003. Bones on the beach: Marine mammal taphonomy of the Colorado Delta, Mexico. Palaios, 18: 168-175.

McAlpine, D.F., Kingsley, M.C.S. and Daoust, P.-Y., 1999. A lactating recordage St. Lawrence beluga (Delphinapterus leucas). Marine Mammal Science, $15: 854-859$.

McAlpine, D.F., Daoust, P.-Y., Brodie, P.F. and Kingsley, M.C.S., 2001. Additional evidence for recent reproductive activity in aged St. Lawrence beluga (Delphinapterus leucas): A reply to Martineau. Marine Mammal Science, 17: $222-226$.

Mudie, P.J. and Short, S.K., 1985. Marine palynology of Baffin Bay, p. 263-308. In J.T. Andrews, ed., Quaternary Environments. Allen and Unwin, Boston.

Nowak, R.M. and Paradiso, J.L., 1983. Walker's Mammals of the World $4^{\text {th }}$ Edition, Vol. 2, p. 569-1362. John Hopkins University Press, Baltimore.

Occhietti, S. and Richard, P.J.H., 2003. Effet réservoir sur les ages ${ }^{14} \mathrm{C}$ de la mer de Champlain à la transition Pléistocène-Holocène: Révision de la chronologie de la déglaciation au Québec méridional. Géographie physique et Quaternaire, 57: 115-138.

Parent, M. and Occhietti, S., 1988. Late Wisconsinan deglaciation and Champlain Sea invasion in the St. Lawrence valley, Québec. Géographie physique et Quaternaire, 42: 215-246.

Prichonnet, G., 1977. La déglaciation de la Vallée du Saint-Laurent et l'invasion marine contemporaine. Géographie physique et Quaternaire, 31: 323 345.

Rochon, A., de Vernal, A., Turon, J.-L., Matthiessen, J. and Head, M.J., 1999. Distribution of dinoflagellate cyst assemblages in surface sediments from the North Atlantic Ocean and adjacent basins and quantitative reconstruction of sea-surface parameters. American Association of Stratigraphic Palynologists, Special Contribution Series 35.

Sergeant, D.E. and Hoek, W., 1988. An update on the status of white whales Delphinapterus leucas in the St. Lawrence Estuary, Canada. Biological Conservation, 45: 287-302

Schäfer, W., 1972. Ecology and Paleoecology of Marine Environments. University of Chicago Press, Chicago, $568 \mathrm{p}$.

Société de Paléontologie du Québec, 2002. Félix: beluga fossile vieux de plus de 10000 ans (Pamphlet published for a display of the specimen at Université du Québec à Montréal).

Steadman, D.W., Kirchgasser, W.T. and Pelkey, D.M., 1994. A Late Pleistocene white whale (Delphinapterus leucas) from Champlain Sea sediments in northern New York, p. 339-345. In E. Lending, ed., Studies in Stratigraphy and Paleontology in Honor of Donald W. Fisher. New York State Museum Bulletin 481, $380 \mathrm{p}$

Stewart, R.E.A., Campana, S.E., Jones, C.M. and Stewart, B.E., 2006. Bomb radiocarbon dating calibrates beluga (Delphinapterus leucas) age estimates. Canadian Journal of Zoology, 84 : 1840-1852.

Van Beneden, P.J. and Gervais, M.P., 1880. Osteographie des cétacés vivants et fossils. Bertrand, Paris.

Wagner, F.J.E., 1967. Published references to Champlain Sea faunas 18371966 and list of fossils. Geological Survey of Canada, Ottawa, Paper 67-16, p. 1-82.

Watson, L., 1981. Sea Guide to Whales of the World. Nelson Canada Limited, Scarborough, $302 \mathrm{p}$ 